\title{
Environmental risk factors for asthma in 13-14 year old African children
}

\author{
Thesis presented for the degree of \\ Masters of Philosophy - Paediatric Pulmonology \\ By \\ Adaeze Chikaodinaka Ayuk \\ Department of Paediatrics and Child Health \\ Faculty of Health Sciences \\ University of Cape Town \\ 2018
}


The copyright of this thesis vests in the author. No quotation from it or information derived from it is to be published without full acknowledgement of the source. The thesis is to be used for private study or noncommercial research purposes only.

Published by the University of Cape Town (UCT) in terms of the non-exclusive license granted to UCT by the author. 


\section{TABLE OF CONTENTS}

\begin{tabular}{|c|c|}
\hline Declaration & 3 \\
\hline Abstract & 4 \\
\hline Acknowledgements & $5-8$ \\
\hline List of Tables & 9 \\
\hline List of Figures & 9 \\
\hline Abbreviations & 9 \\
\hline $\begin{array}{l}\text { A. Chapter 1: Introduction } \\
\text { 1.1 Context } \\
\text { 1.2 Ethical considerations } \\
\text { 1.3 Author Journal guidelines of the Pediatric Pulmonology }\end{array}$ & $\begin{array}{l}10 \\
12 \\
13\end{array}$ \\
\hline $\begin{array}{l}\text { B. Chapter 2: Publication-ready manuscript } \\
\text { 2.1 Candidates contribution, co-authors } \\
2.2 \text { Title page } \\
2.3 \text { Abstract } \\
2.4 \text { Article } \\
2.5 \text { References (article) } \\
\text { 2.6 Figures/Tables }\end{array}$ & $\begin{array}{l}16 \\
17 \\
18 \\
19 \\
30 \\
35\end{array}$ \\
\hline $\begin{array}{l}\text { C. Supporting Documents } \\
\text { 1. Approval of protocol } \\
\text { 2. Instructions to Authors - Pediatric Pulmonology Journal }\end{array}$ & $\begin{array}{l}46 \\
47\end{array}$ \\
\hline
\end{tabular}


Environmental risk factors for asthma in 13-14 year old African children

MPhil A Ayuk 2018

\section{DECLARATION}

I, Adaeze Ayuk, present this thesis in fulfilment of the requirements for the degree of Masters of Philosophy, Paediatric Pulmonology, in the Department of Paediatrics and Child Health, Faculty of Health Sciences, University of Cape Town. The contents of this thesis are entirely the work of the candidate.

This work is original unless otherwise acknowledged and is based on independent work performed by the candidate from data gathered in ISAAC III African centres. The candidate was assisted in the analysis by Jordache Ramjith from the University of Cape town (UCT) and Dr Bill Volmer from the American Thoracic Society/PATSMECOR. The manuscript was written and edited by the candidate with input and comments from the co-authors including the supervisors and collated to form the final manuscript.

No part of this work, either part or whole, has been presented to any other College for a Fellowship nor submitted for another degree to any other university, nor has it been submitted elsewhere by myself or by any other person for publication. This work has not been reported or published prior to registration for the degree of Masters of Philosophy, Paediatric Pulmonology.

Signature and date:

Signed by candidate

February 2018 


\section{ABSTRACT}

BACKGROUND: Asthma prevalence in African children is high and increasing, with more severe disease than that in high income countries. Specific factors driving the rising prevalence or disease severity are poorly understood. The aim of this study was to investigate environmental factors associated with asthma and severity in African children using data obtained from ISAAC III.

METHODS: A population based cross-sectional study of children aged 13 to14 years, from 10 African centres who participated in International Study of Asthma and Allergies in Childhood, (ISAAC) III from randomly selected schools. The prevalence of asthma or severe asthma was calculated for each centre from the ISAAC questionnaire. Environmental exposures assessed for their association with asthma or severe disease, were physical exercise 3 or more times in a week, television watching 5 or more hours in a day, biomass and ETS exposure, consumption of paracetamol at least once a month, large family sizes and having pets in the home from the ISAAC environmental questionnaire. Univariable and multivariable analyses were done adjusting for centre variations. Odds ratio and $95 \%$ confidence intervals $(\mathrm{Cl})$ were calculated.

RESULTS: Amongst 28490 adolescents from 232 schools in 10 African centres (4 middle income and 6 low income), the prevalence of asthma was $12.8 \%$ (95\% Cl 12.4-13.2). Prevalence of severe disease was $8.7 \%(95 \% \mathrm{Cl} 8.4-9.0)$. The significant environmental associations, for current asthma were maternal smoking ( $\mathrm{OR}=1.41 ; 95 \% \mathrm{Cl}: 1.23-1.64)$, exposure to open fire heating ( $\mathrm{OR}=1.28 ; 95 \% \mathrm{Cl}: 1.08$ - 1.51), electric heating (OR=1.13; 95\% $\mathrm{Cl}: 1.01-1.28)$, engaging in strenuous exercise(OR=1.29; $95 \% \mathrm{Cl}$ : 1.11 - 1.50), monthly use of paracetamol(OR 1.23; 95\% $\mathrm{Cl} 1.13$-1.33), or having an elder sibling ( $\mathrm{OR}=0.87 ; 95 \% \mathrm{Cl} 0.77-0.98)$; for severe asthma: maternal smoking (OR=1.61; 95\% Cl: $1.38-1.89)$, cat at home (OR=1.14; 95\% Cl: $1.04-1.25)$, engaging in frequent physical exercise $(\mathrm{OR}=1.42 ; 95 \% \mathrm{Cl}: 1.23-1.64)$ or monthly consumption of paracetamol (OR=1.20; 95\% Cl: 1.07 - 1.34).

CONCLUSION: The study demonstrated several strong, consistent environmental associations with asthma and with severe disease in African children. Strategies to reduce harmful environmental exposures must be strengthened to reduce the burden of childhood asthma in Africa. 
Environmental risk factors for asthma in 13-14 year old African children

MPhil A Ayuk 2018

\section{ACKNOWLEDGEMENTS}

I would like to acknowledge all the co-authors for their contributions as well as the faculty at Methods in Epidemiologic, Clinical and Operations Research (MECOR Africa and Global which are programmes of the American Thoracic Society, ATS), for providing critical review of the manuscript and particularly Bill Volmer, for all their support, comments and encouragements.

I wish to acknowledge the ISAAC III steering committee (and ISAAC III study group*) from which the original data were obtained for analyses.

I would especially like to acknowledge Rodney Erhlich, Landon Myer, Jordache Ramjith and Heather Zar for their supervision and support at different stages of this work. 
Environmental risk factors for asthma in 13-14 year old African children

MPhil A Ayuk 2018

\section{*ISAAC Phase III Study Group}

ISAAC Steering Committee: N Aït-Khaled* (Union Internationale Contre la Tuberculose et les Maladies Respiratoires, Paris, France), H R Anderson (Department of Public Health Sciences, St Georges Hospital Medical School, London, UK), M I Asher (Department of Paediatrics, Faculty of Medical and Health Sciences, The University of Auckland, New Zealand), R Beasley* (Medical Research Institute of New Zealand, Wellington, New Zealand), B Björkstén* (Institute of Environmental Medicine, Karolinska Institutet, Stockholm, Sweden), B Brunekreef (Institute of Risk Assessment Science, Universiteit Utrecht, Netherlands), W Cookson (Asthma Genetics Group, Wellcome Trust Centre for Human Genetics, University of Oxford, UK), J Crane (Wellington Asthma Research Group, Wellington School of Medicine, New Zealand), P Ellwood (Department of Paediatrics, Faculty of Medical and Health Sciences, The University of Auckland, New Zealand), S Foliaki* (Centre for Public Health Research, Massey University, Wellington, New Zealand), U Keil* (Institut für Epidemiologie und Sozialmedizin, Universität Münster, Germany), C K W Lai* (Department of Medicine and Therapeutics, The Chinese University of Hong Kong, SAR China), J Mallol* (Department of Respiratory Medicine, University of Santiago de Chile, Chile), C F Robertson (Department of Respiratory Medicine, Royal Children's Hospital, Parkville, Australia), E A Mitchell (Department of Paediatrics, Faculty of Medical and Health Sciences, The University of Auckland, New Zealand), S Montefort* ("Belvedere”, Naxxor, Malta), J Odhiambo* (Centre Respiratory Diseases Research Unit, Kenya Medical Research Institute, Nairobi, Kenya), N Pearce (Centre for Public Health Research, Massey University, Wellington, New Zealand), J Shah* (Jaslok Hospital \& Research Centre, Mumbai, India), A W Stewart (Population Health, Faculty of Medical and Health Sciences, The University of Auckland, New Zealand), D Strachan (Department of Public Health Sciences, St Georges Hospital Medical School, London, UK), E von Mutius (Dr von Haunerschen Kinderklinik de Universität München, Germany), S K Weiland 
Environmental risk factors for asthma in 13-14 year old African children

MPhil A Ayuk 2018

(Department of Epidemiology, University of Ulm, Germany), $\mathrm{H}$ Williams (Centre for Evidence Based Dermatology, Queen's Medical Centre, University Hospital, Nottingham, UK).

ISAAC International Data Centre: M I Asher, T O Clayton, P Ellwood, T Milne, E A Mitchell, Department of Paediatrics, and AW Stewart, School of Population Health, Faculty of Medical and Health Sciences, The University of Auckland, New Zealand.

ISAAC Phase III National Coordinators: L Ng'ang'a (Kenya), H J Zar (South Africa), Z Bouayad (Morocco), Y-Z Chen (China), C Lai (SAR China), J Shah (India), K Baratawidjaja (Indonesia), S Nishima (Japan), J de Bruyne (Malaysia), F Cua-Lim (Philippines), B-W Lee (Singapore), H-B Lee (South Korea), J-L Huang (Taiwan), P Vichyanond (Thailand), M-R Masjedi (Iran), S Montefort (Malta), N Mahmood (Pakistan), O Al-Rawas (Sultanate of Oman), C E Baena-Cagnani (Argentina), D Solé (Brazil), V Aguirre (Chile), M E Soto-Quirós (Costa Rica), M Baeza-Bacab (Mexico), P Chiarella (Peru), D Holgado (Uruguay), M E Howitt (Barbados), A Priftanji (Albania), M-A Riikjärv (Estonia), J Pekkanen (Finland), M Gotua (Georgia), J Bojarskas (Lithuania), G Lis (Poland), V Ognev (Ukraine), C F Robertson (Australia), M I Asher (New Zealand), G Haidinger (Austria), U Keil (Germany), F Forastiere (Italy), J E Rosado Pinto (Portugal), L García-Marcos (Spain), H R Anderson (UK), P Manning (Republic of Ireland), L Nilsson (Sweden).

ISAAC Phase III Principal Investigators: K Melaku (Ethiopia), F O Esamai, L Ng'ang'a (Kenya), B O Onadeko (Nigeria), H J Zar (South Africa), B Benhabylès (Algeria), Z Bouayad (Morocco), M Jerray (Tunisia), Y-Z Chen, N-S Zhong (China), Y L Lau, G Wong (SAR China), CB Kartasasmita (Indonesia), H Odajima (Japan), KH Teh, J de Bruyne, BS Quah (Malaysia), F Cua-Lim (Philippines), D Y T Goh (Singapore), H-B Lee (South Korea), J-L Huang (Taiwan), P Vichyanond, M Trakultivakorn (Thailand), M-R Masjedi (Iran), J L al-Momen (Kuwait), S Montefort (Malta), N Mahmood (Pakistan), O Al-Rawas (Sultanate of Oman), MK Joshi, V A Khatav, L Kumar, G Setty, K 
Environmental risk factors for asthma in 13-14 year old African children

MPhil A Ayuk 2018

C Jain, T U Sukumaran, S K Sharma, N M Hanumante, AV Pherwani (India), C E Baena-Cagnani (Argentina), N Rosário, G B Fischer, M de Britto, L de Freitas Souza, D Solé (Brazil), L Amarales, P Aguilar, M A Calvo (Chile), M E Soto-Quirós (Costa Rica), I Romieu (Mexico), G Cukier (Panama), J A Guggiari-Chase (Paraguay), P Chiarella (Peru), D Holgado (Uruguay), M E Howitt (Barbados), D Rennie, MR Sears (Canada), G J Redding (USA), A Priftanji (Albania), M-A Riikjärv (Estonia), J Pekkanen (Finland), M Gotua (Georgia), V Svabe (Latvia), J Kudzyte (Lithuania), E G Kondiourina (Russia), G Lis, A Breborowicz (Poland), D Dumitrascu (Romania), H Vogt (Sweden), V Ognev (Ukraine), C F Robertson (Australia), M I Asher, C Moyes, P Pattemore, R Mackay, N Pearce (New Zealand), G Haidinger (Austria), J Weyler (Belgium), P Standring, R Goulding (Channel Islands), U Keil (Germany), A Steriu (Isle of Man), E Bonci, C Galassi, MG Petronio, E Chellini, L Bisanti, F Forastiere, P Sestini, G Ciccone, S Piffer (Italy), R Camâra, J E Rosado Pinto, C Nunes, J M Lopes dos Santos (Portugal), L Clancy (Republic of Ireland), R M Busquets, C González Díaz, L GarcíaMarcos, A Arnedo-Pena, G Garcia Hernández, F Guillén-Grima, M Morales Suarez-Varela, A Blanco Quirós (Spain), H R Anderson, J B Austin, MH Shamssain, D Strachan, M Burr (UK). 
Environmental risk factors for asthma in 13-14 year old African children

MPhil A Ayuk 2018

\section{LIST OF FIGURES}

Figure 1: Flow chart of enrolled participants in environmental ISAAC III study for African Centres

\section{LIST OF TABLES}

Table 1: General data of participants in participating African centres

Table 2: Prevalence rates of asthma in adolescents in various African centres in ISAAC III

Table 3: Prevalence rate and percentage range of environmental risk factors in all African centres

Table 4: Environmental exposures and association with current asthma

Table 5: Environmental exposures and association with severe asthma

\section{Supplementary tables}

Table 6: Environmental exposures and association with current asthma in Anglophone African adolescents participating in ISAAC III

Table 7: Environmental exposures and association with current asthma in Francophone African adolescents participating in ISAAC III

Table 8: Environmental exposures and association with severe asthma in Anglophone African adolescents participating in ISAAC III

Table 9: Environmental exposures and association with severe asthma in Francophone African adolescents participating in ISAAC III

\section{ABBREVIATIONS}

ISAAC - International Study of Asthma and Allergies in Childhood

WQ - Written questionnaire

VQ - Video questionnaire

EQ - Environmental questionnaire

ETS - Environmental tobacco smoke 
Environmental risk factors for asthma in 13-14 year old African children

MPhil A Ayuk 2018

\section{ENVIRONMENTAL RISK FACTORS FOR ASTHMA IN 13 TO 14 YEAR OLD AFRICAN CHILDREN}

Protocol version 3, May 2012- Protocol amendment and re-endorsement October 2017

MPhil Student and Principal investigator

Dr Adaeze Ayuk

Department of Paediatrics and Child Health

Red Cross War Memorial Children's Hospital

University of Cape Town

\section{Supervisor}

Prof. Heather Zar

Department of Paediatrics and Child Health

Red Cross War Memorial Children's Hospital

MRC Unit on Child and Adolescent Health

University of Cape Town

\section{Co-Supervisor}

Jordache Ramjith

Division of Epidemiology \& Biostatistics

School of Public Health \& Family Medicine

University of Cape Town 


\section{Chapter 1}

\section{Introduction}

\subsection{Context:}

Asthma is the commonest chronic disease in children with marked geographic variation in prevalence. ${ }^{1,2}$ Although asthma was considered to be less common in African children compared with those in high income countries, recent data suggests that the African prevalence is as high as the global average and increasing. ${ }^{3-5}$ Gene-environmental interactions may account for much of the international variation in prevalence rates for asthma. ${ }^{6}$ Several environmental factors have been associated with a rise in asthma prevalence. In children, some of these include urban migration, indoor biomass exposure, passive smoke exposure, obesity, vitamin D deficiency and adoption of a more western lifestyle. ${ }^{7}$ In contrast, a rural environment, daycare attendance, and large family size have been associated with a reduced risk for current or severe asthma. ${ }^{7}$ There may be interactions between these factors and a further overlap possibly accounted for by geneenvironmental interactions. ${ }^{8}$

The International Study of Asthma and Allergies in Childhood (ISAAC), is a multi-country cross-sectional survey of the prevalence of asthma, allergic rhino-conjunctivitis and atopic eczema in two age groups of school children: 6 to 7 years and 13 to 14 years. ${ }^{9}$ ISAAC uses standardized questionnaires of reported symptoms to diagnose asthma and to assess severity of disease.

Aim:

The purpose of this study was to investigate the association of environmental factors with asthma prevalence and severity in African children using data obtained from ISAAC III African sites in 13 to 14 year old children. 
Environmental risk factors for asthma in 13-14 year old African children

MPhil A Ayuk 2018

\section{Objectives:}

- To compare the prevalence of current and severe asthma in adolescent participants in ISAAC III in African centres.

- To compare the prevalence of environmental factors associated with (i) current asthma or (ii) severe asthma in these centres.

- To investigate the association of environmental factors with (i) current or (ii) severe asthma in African adolescents.

\section{Relevance}

This work will give insight to what environmental exposures are important in asthma pathogenesis and severity in African children, so informing interventions in this context. This work will also form a basis for future research to reduce the burden of childhood asthma in Africa and to ensure availability of appropriate therapy for management.

Findings from this study can contribute to informing health policies in Africa, such as regulations relating to environmental factors and access to inhaled therapy in African countries.

\subsection{Ethical considerations}

Permission was obtained from both the ISAAC central coordinating centre and UCT research ethics committee (HREC/REF: 209/2012), for analysis of this data. Renewal of ethical clearance was received October 2017. Ethical approval for collection of the data was already obtained from each participant in each centre. 


\subsection{Author guidelines of Pediatric Pulmonology journal}

\section{Main Document}

All manuscript types must include a title page, abstract, text and references in the Main Document. Standard, double-spaced manuscript format, in 12 point font is requested. Number all pages consecutively.

Title page: The title should be brief (no more than 100 characters in length including spaces) and useful for indexing. All authors' names with highest academic degree, affiliation of each, but no position or rank, should be listed. For cooperative studies, the institution where research was primarily done should be indicated. In a separate paragraph, specify grants, other financial support received, and the granting institutions (grant number(s) and contact name(s) should be indicated on the title page). If support from manufacturers of products used is listed, assurances about the absence of bias by the sponsor and principal author must be given. Identify meetings, if any, at which the paper was presented. The name, complete mailing address, telephone number, fax number, and e-mail address of the person to whom correspondence and reprint requests are to be sent must be included. Keywords should also be noted on the title page. For usage as a running head, provide an abbreviated title (maximum 50 characters) on the bottom of the title page.

Summary/Abstract: In accordance with the structure of the article, with or without separate headings, outline the objectives, working hypothesis, study design, patient-subject selection, methodology, results (including numerical findings) and conclusions. The Summary should not exceed the word counts outlined above. If abbreviations are used several times, spell out the words followed by the abbreviations in parentheses.

Acknowledgements: Technical assistance, advice, referral of patients, etc. may be briefly acknowledged at the end of the text under "Acknowledgements."

Informed Consent: Informed consent statements, if applicable, should be included in the Methods section.

References/citations: References may be included at the end of your text or uploaded as a separate file. Ensure your references are up to date and include a critical selection from the world literature. References should be prepared according to CSE (Council of Science Editors) citation-sequence style. Refer to the Scientific Style and Format: The CSE Manual for Authors, Editors, and Publishers, 8th edition (University of Chicago Press). Start the listing on a new page, double-spaced throughout.

Number the references in the sequence in which they first appear in the text, listing each only once even though it may be cited repeatedly.

When citing a reference in the text, the style advocated by CSE suggests numbers appear in superscript and appear before punctuation marks (commas or periods). In the citation-sequence 
system, sources are numbered by order of reference so that the first reference cited in the paper is 1 , the second 2 , and so on. If the numbers are not in a continuous sequence, use commas (with no spaces) between numbers. If you have more than two numbers in a continuous sequence, use the first and last number of the sequence joined by a hyphen, for example 2,4,6-10.

In the references, list the first ten authors of the cited paper. If there are more than ten authors, list the first 10 authors followed by 'et al'. Journals' names should be shown by their abbreviated title in Index Medicus. Manuscripts in preparation or submitted for publication are not acceptable references. If a manuscript "in press" is used as a reference, a copy of it must be provided with your submission. For a book reference only include the page numbers that have direct bearing on the work described.

Keywords: On the title page, supply a minimum of 3 to 5 keywords, exclusive of words in the title of the manuscript. A guide to medical subject heading terms used by PubMed is available at http://www.nlm.nih.gov/mesh/MBrowser.html

Abbreviations: Define abbreviations when they first occur in the manuscript and from there on use only the abbreviation. Whenever standardized abbreviations are available use those. Use standard symbols with subscripts and superscripts in their proper place.

Formatting Specific to Original Research Articles: Divide article into: Title Page, Summary/Abstract, Introduction, Materials and Methods, Results, Discussion, and References, starting each section on a new page. All methodology and description of experimental subjects should be under Materials and Methods; results should not be included in the Introduction. Please ensure the following appears in the appropriate section of your manuscript:

$>$ a concise introductory statement outlining the specific aims of the study and providing a discussion of how each aim was fulfilled;

$>$ a succinct description of the working hypothesis;

$>$ a detailed explanation of assumptions and choices made regarding study design and methodology;

$>$ a description of the reasons for choosing the type and number of experimental subjects (patients, animals, controls) and individual measurements; if applicable, information about how and why the numbers may differ from an ideal design (e.g., the number required for achieving 90\% confidence in eliminating Type II error);

$>$ specifics about statistical principles, techniques and calculations employed and, if applicable, methods for rejecting the null hypothesis;

$>$ a concise comparison of the results with those of conflicting or confirmatory studies in the literature;

$>$ a brief summary of the limitations of the scientific methods and results; and

$>$ a brief discussion of the implications of the findings for the field and for future studies.

Tables 
Tables should not be included in the Main Document but submitted as a separate DOC or RTF file. Number tables with Arabic numbers consecutively and in order of appearance. Type each table double-spaced on a separate page, captions typed above the tabular material. Symbols for units should be used only in column headings. Do not use internal horizontal or vertical lines; place horizontal lines between table caption and column heading, under column headings, and at the bottom of the table (above the footnotes if any). Use footnote letters ( $a, b, c$, etc.) in consistent order in each table. All tables should be referred to in the text. Do not submit tables as photographs and do not separate legends from tables.

\section{REFERENCES}

1. ISAAC Steering Committee. Worldwide variations in the prevalence of asthma symptoms: the International Study of Asthma and Allergies in Childhood (ISAAC). Eur Respir J 1998; 12: 315- 335.

2. Asher MI, Montefort S, Bjorksten B, Lai CK, Strachan DP, et al. (2006) Worldwide time trends in the prevalence of symptoms of asthma, allergic rhinoconjunctivitis, and eczema in childhood: ISAAC Phases One and Three repeat multicountry cross-sectional surveys. Lancet 2006; 368: 733-743.

3. Adeloye D, Yee Chan K, Rudan I, Campbell H. An estimate of asthma prevalence in Africa: a systematic analysis. Croat Med J. 2013; 54(6): 519-531. doi: 10.3325/cmj.2013.54.519 PMCID: PMC3893990

4. Ait-Khaled N, Odhiambo J, Pearce N, Adjoh KS, Maesano IA, Benhabyles B et al. Prevalence of symptoms of asthma, rhinitis and eczema in 13- to 14-year-old children in Africa: the International Study of Asthma and Allergies in Childhood Phase III. Allergy. 2007;62:247-584:

5. Zar HJ, Ehrlich RI, Workman L, Weinberg EG. The changing prevalence of asthma, allergic rhinitis and atopic eczema in African adolescents from 1995 to 2002. Pediatr Allergy Immunol. 2007; 18:560-5

6. McLeish S, Turner SW. Gene-environment interactions in asthma Arch Dis Child. 2007; 92(11): 1032-1035. doi: 10.1136/adc.2006.112185.PMCID: PMC2083615

7. Cole Johnson C, Ownby DR, Zoratti EM, Alford SH, Williams LK, Joseph CLM. Environmental Epidemiology of Pediatric Asthma and Allergy. Epidemiol Rev 2002; 24: 154-175.

8. Martinez FD. Genes, environments, development and asthma: a reappraisal. ERJ 2007 29: 179-184; DOI: 10.1183/09031936.00087906

9. Ellwood P, Asher MI, Beasley R. The international study of asthma and allergies in childhood (ISAAC): phase three rationale and methods. Int J Tuberc Lung Dis 2005; 9:1016. 
Environmental risk factors for asthma in 13-14 year old African children

MPhil A Ayuk 2018

\section{CHAPTER 2}

\section{PUBLICATION READY MANUSCRIPT}

Environmental risk factors for asthma in 13-14 year old African children

\section{Co-Authors:}

HJ Zar', J Ramjith ${ }^{2}$

${ }^{1}$ Department of Paediatrics and Child Health, Red Cross War Memorial Children's Hospital, School of Public Health \& Family Medicine, Faculty of Health Sciences, University of Cape Town, ${ }^{2}$

\section{Contribution of the candidate}

The candidate undertook the data analysis and interpretation of data with biostatistical assistance from Jordache Ramjith and William Vollmer (Centre for Health Research, Kaiser Permanente, Portland, Oregon USA). 
Environmental risk factors for asthma in 13-14 year old African children

MPhil A Ayuk 2018

\section{ENVIRONMENTAL RISK FACTORS FOR ASTHMA IN 13-14 YEAR OLD AFRICAN CHILDREN}

Adaeze C Ayuk MBBS, FMCPaed ${ }^{1,3}$

Jordache Ramjith BSc, BSc Hons, MSc ${ }^{4}$

Heather J Zar MB ChB, FCPaeds, FRCP, PhD ${ }^{1,2}$

${ }^{1}$ Department of Paediatrics and Child Health, Red Cross War Memorial Children's Hospital University of Cape Town, South Africa, ${ }^{2}$ MRC Unit of Child \& Adolescent Health, University of Cape Town, South Africa, ${ }^{3}$ Department of Paediatrics University of Nigeria Teaching Hospital Enugu Nigeria, ${ }^{4}$ Division of Epidemiology \& Biostatistics, School of Public Health \& Family Medicine, Faculty of Health Sciences, University of Cape Town.

\section{Correspondence:}

Dr AC Ayuk

adaraymond@yahoo.com

$+2348036754123$

$+27846870158$

KEY WORDS: Africa, asthma, environment, risk, severe, adolescents, ISAAC

RUNNING HEAD: Environmental risk factors for current or severe asthma in Africa 


\section{ABSTRACT}

BACKGROUND: Asthma prevalence in African children is high and increasing, with more severe disease than that in high income countries. Specific factors driving the rising prevalence or disease severity are poorly understood. The aim of this study was to investigate environmental factors associated with asthma and severity in African children using data obtained from International Study of Asthma and Allergies in Childhood, (ISAAC) III.

METHODS: A population based cross-sectional study of children aged 13-14 years from 10 African centres who participated in ISAAC III from randomly selected schools. The prevalence of asthma or severe asthma was calculated for each centre. Self-reported environmental exposures included engaging in physical exercise, television watching, biomass and ETS exposure, consumption of paracetamol, large family sizes and having pets in the home. Univariable and multivariable analyses were done adjusting for centre variations. Odds ratio and respective $95 \%$ confidence intervals $(\mathrm{Cl})$ were calculated.

RESULTS: Amongst 28490 adolescents from 232 schools in 10 African centres (4 middle income and 6 low income), the prevalence of asthma was $12.8 \%$ (Cl 12.4-13.2), while prevalence of severe disease was $8.7 \%$ ( $\mathrm{Cl} 8.4-8.0)$. Factors most strongly associated with asthma were maternal smoking ( $\mathrm{OR}=1.41 ; 95 \% \mathrm{Cl}: 1.23-1.64)$, exposure to open fire heating (OR=1.28; 95\% $\mathrm{Cl}: 1.08$ - 1.51) and electric heating ( $\mathrm{OR}=1.13 ; 95 \% \mathrm{Cl}: 1.01$ - 1.28), engaging in strenuous exercise $(\mathrm{OR}=1.29 ; 95 \% \mathrm{Cl}: 1.11-1.50$ and monthly use of paracetamol (OR $1.23 ; 95 \% \mathrm{Cl} 1.13$ 1.33 , while having an elder sibling was protective for asthma (OR=0.87; $95 \% \mathrm{Cl} 0.77-0.98$ ). Factors strongly associated with severe asthma were maternal smoking ( $\mathrm{OR}=1.61 ; 95 \% \mathrm{Cl}: 1.38$ $1.89)$, having a cat pet at home $(\mathrm{OR}=1.14 ; 95 \% \mathrm{Cl}: 1.04-1.25)$, engaging in $\geq 3$ weekly physical exercise $(\mathrm{OR}=1.42 ; 95 \% \mathrm{Cl}: 1.23$ - 1.64) and monthly consumption of paracetamol (OR=1.20; 95\% Cl: 1.07 1.34$)$.

CONCLUSION: There was a high prevalence of severe asthma in African children. Several environmental exposures were associated with asthma or with severe disease. Strategies to reduce harmful environmental exposures must be strengthened to reduce the burden of childhood asthma in Africa.

\section{Word count:}

Abstract $=340$ Text $=2224$ Tables $=5 \quad$ Figures $=1$ Supplementary tables $=4$

References $=40$

Key words: Asthma, adolescents, risk factors, environmental, ISAAC III 
Environmental risk factors for asthma in 13-14 year old African children

MPhil A Ayuk 2018

\section{Introduction}

Asthma is the commonest chronic disease in children with marked geographic variation in prevalence $^{1,2}$. Asthma was considered to be less common in African children compared with those in high income countries, however recent data from African studies suggests that the prevalence is as high as the global average and increasing ${ }^{1-5}$. Furthermore, a high proportion of African children with asthma have severe disease ${ }^{6}$. Several environmental factors have been associated with the rise in asthma prevalence, but these have not been well studied in African children. Further, comparison of findings across African countries is complicated by lack of consistency in methods to define and assess asthma prevalence and severity and to measure environmental exposures.

The International Study of Asthma and Allergies in Childhood (ISAAC) study is a multi-country cross-sectional survey of the prevalence of asthma, allergic rhino-conjunctivitis and atopic eczema in two age groups of school children: 6 to 7 years and 13 to 14 years $^{7}$. ISAAC used standardized written questionnaires of reported symptoms. The ISAAC study phases allow standardized comparisons of the prevalence of these disorders in different countries. An environmental questionnaire was included in the latest phase of ISAAC (ISAAC III), enabling investigation of environmental factors associated with prevalence or severity of disease. The use of the written questionnaire (WQ) was compulsory for every centre participating in ISAAC III, whiles the use of the environmental questionnaire (EQ) was optional ${ }^{7}$. Although 10 African sites in Africa participated in ISAAC III, the results from the environmental influences on asthma in African respondents have not yet been published.

Several potentially harmful environmental exposures associated with asthma or severe disease are ubiquitous in Africa. Studies suggest that urbanizing populations may be especially susceptible to development of asthma, possibly through changes in diet and lifestyle and 
Environmental risk factors for asthma in 13-14 year old African children

MPhil A Ayuk 2018

exposure to environmental pollutants. Key prevalent environmental factors in Africa include exposure to diverse types of biomass for cooking or heating the home, exposure to tobacco smoke, large family sizes, pets in the home, frequent lower respiratory tract infection and life style changes that include transition to more sedentary living ${ }^{3}$.

Prior South African studies in children ${ }^{8}$ have reported an association between current asthma and parental environmental tobacco exposure in school children although this was not found in a Kenyan study ${ }^{9}$. Another Kenyan study reported that cooking with kerosene increased the risk of exercise induced bronchospasm (EIB) while the use of open fire for heating did not lead to adverse respiratory effects ${ }^{10}$. These studies have limited generalizability as they were conducted in single centres, using varied methods.

The aim of this study was to investigate environmental factors associated with asthma prevalence or severity in 13 to 14 year old African adolescents participating in ISAAC III. 
Environmental risk factors for asthma in 13-14 year old African children

MPhil A Ayuk 2018

\section{Materials and Methods}

This was a cross-sectional study of African adolescents aged 13 to 14 years who participated in ISAAC III in African centres. Participants completed both core written questionnaire and environmental questionnaires of ISAAC III. The African data was obtained, with permission, from the ISAAC data centre. The study was approved by the Faculty of Health Sciences University of Cape town research ethics committee. Each participating centre also obtained ethics approval for the initial data collection at their sites.

Data Collection and Quality Control: The core and environmental questionnaires were completed according to standardized ISAAC III methodology ${ }^{7}$. Centres that administered the questionnaires in languages other than English (Afrikaans, Xhosa, Arhmaic, French, Arabic) underwent a back- translation process as per ISAAC protocol ${ }^{7}$. Further sub-categorization for purposes of comparison by language (cultural) divide into Anglophone and Francophone countries was also done, this may impact on their environmental influences. Double data entry was done at individual sites to minimize data entry errors and each centre was responsible for initial data cleaning. Cleaned data that was transferred to the central ISAAC data centre in New Zealand was utilized with careful quality control of data for analysis. This was further cleaned by the researcher.

The self- administered written questionnaire (WQ) used for the study included questions on respiratory symptoms, while the environmental questionnaires (EQ) consisted of questions covering exposures to biomass fuels, tobacco smoke and pets, physical activity, number of older and younger siblings and socioeconomic factors.

Current asthma was defined according to the ISAAC definition, as wheezing or whistling in the chest in the past 12 months. Severe asthma was defined according to ISAAC as any of the 
Environmental risk factors for asthma in 13-14 year old African children

MPhil A Ayuk 2018

following in the past 12 months: more than 3 attacks of wheezing, sleep disturbed by wheezing on average 1 or more nights per week, or at least one episode where wheezing limited speech to only one or two words at a time between breaths. These were the primary outcome variables for the study and were analyzed independently of each other.

The following variables were analysed from the Environmental questionnaire(EQ): exposure to cooking and biomass fuels: electric cooking, gas cooking, open fire cooking, electric heating, gas heating, open fire heating (yes or no to each of electricity, gas, and open fires, with possibility of answering yes to more than one type); second-hand smoke exposure- Environmental Tobacco Smoke (ETS), which we analysed with separate analyses for mother, father and any persons smoking at home, ${ }^{11}$ (recoded as ETS in $\geq 3$ smokers as we noted that any additional smoker in the house may include the adolescent participant). This was captured as ETS in $\geq 3$ smokers at home, to enable the analyses account additional smokers beyond the mother and father. Other variables were: having $\geq 2$ older siblings, having $\geq 2$ younger siblings, having pets at home (cat and dog), engaging in $\geq 3$ weekly physical exercise, sedentary life style such as $\geq 5$ hours of daily television watching and use of paracetamol at least once a month as compared to once or less in a year ${ }^{110}$. Data analyses

Data were analyzed using Stata version 13 (Stata Corporation). The participants who met WQ criteria were identified from the data and were correlated with their answers to the EQ as possible risk factors for their symptoms. In the questionnaire, a "yes" answer was written as "1", "no" as " 0 " while any other answers were completed " 9 ". All " 9 " were said to be indeterminate and were treated as negative answers; the frequency of such data was however less than $5 \%$ for each of the above environmental and lifestyle variables. All environmental factors were analyzed as simple binary variables. 
Environmental risk factors for asthma in 13-14 year old African children

MPhil A Ayuk 2018

Univariable and multivariable logistic regression analyses were used to assess the relationship between the environmental and lifestyle variables adjusted for centre with current and severe asthma. For children who indicated current asthma, a univariable logistic regression analysis was performed to assess the relationship between the environmental and lifestyle variables adjusted for centre. Similar analyses were also done for children with severe asthma. All variables with a p-value $<0.2$ were then built into a multivariable logistic regression model and a backward selection procedure was used to identify significant variables. Each model included 232 clusters for school attended to adjust for the correlation between children attending the same school in the standard errors of the estimated effects of the risk factors. The key findings were compared between the Anglophone and Francophone centres. All regression outputs were summarized as odds ratios (ORs) and corresponding 95\% confidence intervals (Cls). A p-value $<0.05$ was considered statistically significant.

\section{Results}

Participants: There were Amongst-258,267 children who were recruited among the 13 to 14 year-old and participated in ISAAC III from 10 centres in 7 African countries. Of these, there were 28,490 respondents from 232 schools that completed both the written questionnaire (WQ) and environmental questionnaire (EQ), and whose results were analyzed, fig 1 . The ten centres were geographically spread across Africa- three Anglophone centres in South, East and West Africa (Cape Town, Addis Ababa, Ibadan); and seven Francophone centres in Central, West, North and East Africa (Yaoundé, Urban Cote d'Ivoire, Port-gentil, Boulmene, Casablanca, Marrakech, Khartoum). Fifty percent of overall respondents were male with a variation of sex distribution across centres. There were four middle-income centres and six low-income centres. The average response rate was $92.8 \%$ across centres, table 1 . 
Environmental risk factors for asthma in 13-14 year old African children

MPhil A Ayuk 2018

Asthma prevalence: The overall prevalence of current asthma was $12.8 \%$ [95\% Cl 12.4-13.2], while the prevalence of severe asthma was $8.7 \%$ (95\% Cl 8.4-9.0); table 2. There was a 4.5-fold difference in the prevalence of current asthma between centres with the highest and lowest prevalence rates, table 2. The highest prevalence occurred in Cape Town, South Africa $20.4 \%$ (95\% $\mathrm{Cl} 19.3-21.5)$ and Urban Cote d'Ivoire, Ivory Coast $19.3 \%$ (95\% Cl 18.0-20.7) while the lowest prevalence was in Boulmene, Morocco 5.4\% (95\% Cl 4.2 -6.8) and Marrakech, Morocco $4.4 \%(95 \% \mathrm{Cl} 3.5-5.5)$.

Prevalence of environmental risk factors: There was wide variability in prevalence of environmental factors across centres, table 3 . Across sites, the use of gas for cooking $[17,967$ (63.1\%)], was twice as common compared to other cooking exposures: electricity, $7,327(25.7 \%)$ or use of open fires, $8051(28.3 \%), p<0.001$. Exposure to gas as a means of home heating, was however the least common way of heating homes used by $3,333(11.7 \%)$, table 3 . There was a high prevalence of large family size reported in all African sites, where 24,378 (85.6\%) of respondents had two or more older siblings and 23,811 (83.6\%) had two or more younger siblings. Exposure to environmental tobacco smoke (ETS) was common: 15,371 (54.0\%) children reported homes with 3 or more smokers. There were 1,959 (6.9\%) who reported mothers who smoked, and 6,156 (21.6\%) had a dad who smoked at home. Cat exposure occurred in 11,043 $(38.8 \%)$ of homes, while dog exposure was less common in $9,596(33.7 \%)$ homes, $p<0.001$. A sedentary lifestyle as assessed by watching television 5 or more hours per day occurred in 9603 (33.7\%) participants, while engaging in regular physical exercise was only reported by 5,613 (19.7\%); $p<0.001$. Paracetamol was reported to be consumed at least once a month by 11,654 (40.9\%), table 3.

Asthma and environmental risk factors: Environmental factors associated with current asthma on univariable analyses were maternal smoking ( $\mathrm{OR}=1.42 ; 95 \% \mathrm{Cl}: 1.23-1.64 ; \mathrm{p}<0.001)$, 
Environmental risk factors for asthma in 13-14 year old African children

MPhil A Ayuk 2018

paternal smoking $(\mathrm{OR}=1.14 ; 95 \% \mathrm{Cl}$ : $1.03-1.26, \mathrm{p}=0.01)$, use of open fires $(\mathrm{OR}=1.28 ; 95 \% \mathrm{Cl}$ : $1.05-1.43 ; p=0.01)$ or electricity $(\mathrm{OR}=1.12 ; 95 \% \mathrm{Cl}: 1.00-1.26 ; \mathrm{p}=0.05)$ for home heating, having a cat at home $(\mathrm{OR}=1.13 ; 95 \% \mathrm{Cl} 1.03-1,23 ; \mathrm{p}=0.01)$, engaging in weekly physical exercise three or more times every week $(\mathrm{OR}=1.31 ; 95 \% \mathrm{Cl}: 1.14-1.51 ; \mathrm{p}<0.001)$, consumption of paracetamol at least once a month (OR 1.24; 95\% Cl 1.15 - 1.35; $\mathrm{p}<0.001)$. Respondents who had 2 or more older siblings had a reduced risk of current asthma (OR $0.88 ; 95 \% \mathrm{Cl} 0.78-1.00 ; \mathrm{p}$ $=0.04)$, table 4 .

Environmental risk factors associated with severe asthma on univariable analyses were exposure to ETS: maternal smoking (OR 1.63; 95\% $\mathrm{Cl} 1.39$-1.90; $p<0.001)$, paternal smoking (OR $1.1595 \% \mathrm{Cl} 1.03-1.29 ; \mathrm{p}=0.02)$; and other smokers at home (OR $1.1795 \% \mathrm{Cl} 1.03-1.34 ; p=0.02$ ); having a cat at home $(\mathrm{OR}=1.17 ; 95 \% \mathrm{Cl} 1.07-1,29 ; \mathrm{p}=0.001)$, engaging in physical exercise 3 or more times every week (OR 1.42; 95\% Cl $1.23-1.63 ; p=<0.001)$ and ingestion of paracetamol at least once a month (OR 1.21, 95\% $\mathrm{Cl} 1.09-1.36 ; \mathrm{p}=0.001)$.

On multivariable analysis, factors associated with current asthma were maternal smoking (OR $1.41 ; 95 \% \mathrm{Cl} 1.23-1.64 ; \mathrm{p}<0.001$ ), heating the home with electricity (OR 1.13; 95\% Cl 1.011.28; $p=0.04)$, open fires ( $\mathrm{OR} 1.28 ; 95 \% \mathrm{Cl} 1.08-1.51 ; p=0.01)$, engaging in regular strenuous physical exercise (OR 1.29; 95\% Cl 1.11, 1.50; $\mathrm{p}=0.001)$, consumption of paracetamol at least once a month (OR 1.23; 95\% $\mathrm{Cl} 1.13-1.33 ; \mathrm{p}<0.001)$, while having 2 or more older siblings was protective (OR 0.87; 95\% Cl 0.77-0.98; $\mathrm{p}=0.03$ ), table 5 .

On multivariable analysis, factors associated with severe asthma were maternal smoking $(\mathrm{OR}=1.61 ; 95 \% \mathrm{Cl}: 1.38-1.89 ; \mathrm{p}<0.001)$, having a cat at home $(\mathrm{OR}=1.14 ; 95 \% \mathrm{Cl} 1.04-1.25$; $p=0.03)$, engaging in frequent physical exercise $(\mathrm{OR}=1.42 ; 95 \% \mathrm{Cl}: 1.23-1.64 ; \mathrm{p}<0.001)$ or paracetamol at least once every month (OR 1.20; $95 \% \mathrm{Cl} 1.07-1.34 ; \mathrm{p}<0.001$ ), table 5. 
Environmental risk factors for asthma in 13-14 year old African children

MPhil A Ayuk 2018

Asthma and environmental risk factors in Anglophone compared to Francophone countries

When analyzed by language divide, asthma prevalence in the Anglophone countries was $15.1 \%$ (1723/11381), $95 \% \mathrm{Cl} 14.5$ to 15.8$)$, compared to $11.3 \%$ (1927/17109), $95 \% \mathrm{Cl} 10.8$ to 11.8$)$, in Francophone sites, $\mathrm{p}<0.001$. Severe asthma prevalence was $11.0 \%(1257 / 11381), 95 \% \mathrm{Cl} 10.5$ to 11.6), and 7.1\% (1214/17109), 95\% Cl 6.7 to 7.5), respectively in Anglophone vs. Francophone countries, $p=<0.001$.

In a multivariable analysis, the important environmental influences for asthma that were present in both areas included maternal smoking, $\geq 3$ weekly physical exercise or monthly paracetamol use. In addition in Anglophone countries associations were found for cat in the home (OR=1.26; $95 \% \mathrm{Cl} 1.11$ to $1.39 ; \mathrm{p}<0.001)$, and a protective role for use of gas for heating (OR=0.80; $95 \% \mathrm{Cl} 0.67$ to $0.96 ; \mathrm{p}=0.02$ ) while in Francophone countries, gas heating $(\mathrm{OR}=1.31$; $95 \% \mathrm{Cl} 1.09$ to $1.57 ; \mathrm{p}=0.003)$ or fire heating $(\mathrm{OR}=1.25 ; 95 \% \mathrm{Cl} 1.01$ to $1.56 ; \mathrm{p}=0.04)$ were significantly associated with asthma, (supplementary Tables 6 and 7).

There were similar associations with severe asthma in Anglophone and Francophone countries including maternal smoking ( $\mathrm{OR}=1.38 ; 95 \% \mathrm{Cl} 1.05$ to $1.83 ; \mathrm{p}=0.02)$, engaging in strenuous exercise $(\mathrm{OR}=1.58 ; 95 \% \mathrm{Cl} 1.25$ to $2.02 ; \mathrm{p}=0.002)$ and monthly paracetamol exposure $(\mathrm{OR}=1.23$; 95\% $\mathrm{Cl} 1.08$ to 1.41; $\mathrm{p}=0.003$ ); (supplementary Tables 8 and 9).

\section{Discussion}

This large study of asthma in African adolescents participating in ISAAC III has shown high prevalence rates of asthma with a high proportion having severe asthma. Several environmental factors were highly prevalent and were associated with asthma or severe disease. Asthma prevalence was associated with use of open fires and electricity for heating the home, maternal smoking, $\geq 3$ weekly physical exercise and monthly paracetamol consumption 
Environmental risk factors for asthma in 13-14 year old African children

MPhil A Ayuk 2018

and having an older sibling; while severe asthma was associated with exposure to maternal smoking, gas for home heating, frequent physical exercise and paracetamol consumption. There were consistent exposures associations with severe asthma in both Anglophone and Francophone countries.

Our study showed that smoke exposure was a significant risk factor for childhood asthma and for severe disease, as has been previously reported in many African countries ${ }^{8,121-}$ 165. These findings add to the evidence for the adverse impact of Environmental tobacco smoke (ETS), on lung health in children and adolescents. This is especially important in Africa where the prevalence of smoking is increasing and where adolescents may be at an increased risk of becoming smokers ${ }^{16,17,18}$. The association of asthma with ETS exposure even occurred in areas with a low prevalence of maternal smoking. Cigarette smoking and second-hand smoke exposure of any intensity are well documented triggers of asthma ${ }^{19-21}$. The association may be due to direct toxin effects on the bronchial epithelium and cilia, causing oxidative damage, and making the airway asthma- prone ${ }^{221}$. ETS exposure to the airways also causes the release of proinflammatory mediators and resultant increase in epithelial permeability which leads to mucosal edema and this contributes to asthma symptoms ${ }^{22}$. Furthermore, cumulative exposure to tobacco smoke culminates in a decline in lung function: approximately $18 \%$ in forced expiratory volume in 1 second (FEV1) over a ten-year period ${ }^{23}$.

Many households in low and middle-income countries burn biomass fuels in open fireplaces or in non-airtight cooking or heating stoves. This results in substantial emissions, with high levels of indoor pollution. Biomass exposure to wood for cooking or heating the home thus poses a significant risk for current asthma, due to high level of respirable particulate matter, further confirming findings from other studies ${ }^{243-265}$. Many wood smoke constituents cause both acute and chronic biologic, physiologic, and structural effects in the lungs including obstructive symptoms ${ }^{26}$. Further use of gas for heating or cooking is increasingly occurring in these areas, as 
Environmental risk factors for asthma in 13-14 year old African children

MPhil A Ayuk 2018

the population becomes less poor. However, concerning data suggests that exposure to volatile organic compounds (from paraffin or gas) may be associated with substantial respiratory morbidity including wheezing 25,26 .

In those with older siblings, a protective effect was noted, as has been reported in other studies $^{27-31}$. Large family size was however not associated with severe asthma in this present study. This may be because the protective effect of frequent exposures to infection that comes from having many siblings, which influences the TH 1 pathway in the "hygiene hypothesis" may not totally account for the other inflammation pathways involved in developing severe asthma.

There was an increased risk of current asthma in children who engaged in frequent physical exercise as seen in other studies ${ }^{32,33}$. Exercise may precipitate asthma and though the exact mechanism is unknown, two theories are promulgated: the airway humidity theory, which suggests that air movement through the airway results in relative drying of the airway that serves as a trigger to a cascade of events that results in airway edema and bronchospasm. The other theory, based on airway cooling phenomenon where the moving air in the bronchial tree results in a decreased temperature of the bronchi, which triggers a hyperemic response in an effort to heat the airway. This also culminates in release of inflammatory mediators with resultant bronchial wall spasm ${ }^{34}$. However, it is also possible that exercise unmasked asthma symptoms in children with underlying or undiagnosed asthma.

There was a consistent significant association in our study between current and severe asthma with monthly paracetamol consumption as also seen in various other studies ${ }^{35-40}$. Paracetamol when consumed, causes the total glutathione levels rise and this has been associated with marked functional bronchoconstriction. ${ }^{40}$ These levels are reported to be increased in induced sputum of patients with mild and moderate asthma ${ }^{38}$, further buttressing the contribution of oxidative stress to the pathogenesis of airway inflammation. 
Environmental risk factors for asthma in 13-14 year old African children

MPhil A Ayuk 2018

One limitation of the study is reliance on recall and on written response to wheezing or whistling in chest in past 12 months as the measure of current asthma, especially as there is no word for wheezing in many African languages. However, this method has been widely used in ISAAC for the diagnosis of asthma. Ass, this was a cross-sectional study causality cannot be inferred. Also indoor air pollution or biomass exposure was not objectively measured. The sample was not weighted for the true population sizes and the centres that did not complete the environmental questionnaire, and thus excluded from analysis, may affect generalizability of results. However, the sites studied were widely spread across geographical divisions of Africa, represent a large number of children and are thus a representative sample. Further, differences across sites and schools within sites were accounted for in the regression analysis.

In conclusion, this study highlights that asthma is common and often severe in African children and that there are specific environmental exposures associated with disease. Several exposures of public health importance were identified, highlighting the need for stronger health policies and programs to reduce exposures associated with disease. Strategies to promote cleaner fuels and reduce smoking are urgently needed in African countries to improve child health.

\section{Conflict of interest}

None 


\section{References}

1. ISAAC Steering Committee. Worldwide variations in the prevalence of asthma symptoms: The International Study of Asthma and Allergies in Childhood (ISAAC). Eur Respir J 1998; 12: 315- 35.

2. Mallola J, Craneb J von Mutiusc E, Odhiambo J, Keile U, Stewartf A, the ISAAC Phase Three Study Group. The International Study of Asthma and Allergies in Childhood (ISAAC) Phase Three: A global synthesis. Allergol Immunopathol 2013;41: 73-85.

3. Adeloye D, Yee Chan K, Rudan I, Campbell H. An estimate of asthma prevalence in Africa: a systematic analysis. Croat Med J 2013; 54(6): 519-531. doi: 10.3325/cmj.2013.54.519 PMCID: PMC3893990.

4. Sears MR. Trends in the Prevalence of Asthma Chest 2014;145: 219-25.

5. Zar HJ, Ehrlich RI, Workman L, Weinberg EG. The changing prevalence of asthma, allergic rhinitis and atopic eczema in African adolescents from 1995 to 2002. Pediatr Allergy Immunol. 2007; 18:560-5.

6. The Global Asthma Report 2014. Available at http://www.globalasthmareport.org/burden/burden.php. Last accessed February 2018.

7. Ellwood P, Asher MI, Beasley R. The international study of asthma and allergies in childhood (ISAAC): phase three rationale and methods. Int J Tuberc Lung Dis 2005; 9:1016.

8. Ehrlich RI, Du Toit D, Jordaan E, Potter P, Volmink JA, Weinberg E. Risk factors for childhood asthma and wheezing- Importance of maternal and household smoking. Am J Respir Crit Care Med 1996; 154: 681- 8.

9. Mohamed N, Ng'ang'a L, Odhiambo J, Nyamwaya J, Menzies R. Home environment and asthma in Kenyan school children: a case-control study. Thorax 1995:50:74-8. 
10. Ng'ang'a LW, Odhiambo JA, Mungai MW. Prevalence of exercise induced bronchospasm in Kenyan school children: an urban-rural comparison. Thorax 1998; 53: 919- 26.

11. Environmental questionnaire ISAAC Document 082. ISAAC Phase Three. Available at http://isaac.auckland.ac.nz/phases/phasethree/phasethree.html Last accessed April 2018.

12. WHO. WHO report on the global tobacco epidemic 2013. WHO; 2013 [cited October 2014].

13. Msyamboza KP, Mvula C, Kathyola D. Prevalence and eorrelates of tobacco smoking, use of smokeless tobacco and passive smoking in adult Malawians: National populationbased NCD STEPS survey. Science Postprint 2013; 1(1): e00002. doi:10.14340/spp.2013.10A0004

14. Maluleke KR, Worku Z. Environmental Determinants of asthma among school children aged 13-14 in and around Polokwane, Limpopo province, South Africa. Int. J. Environ. Res. Public Health 2009; 6: 2354-74.

15. Ehrlich RI, du Toit D, Jordaan E, Potter P, Weinberg E, Ұolmink J, Zwarenstein M, Weinberg E. Household smoking and bronchial hyper responsiveness in asthmatic children J Asthma 2001;3: 239-51.

16. Butz AM, Halterman JS, Bellin M, Tsoukleris $M$, Đonithan $M$, Kub J et al. Factors

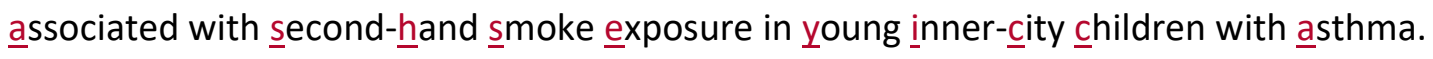
Journal of Asthma 2011; 48:449-57.

17. Rudatsikira E, Abdo A, Muula AS. Prevalence and determinants of adolescent tobacco smoking in Addis Ababa, Ethiopia. BMC Public Health 2007; 7:176.

18. Peltzer K. Tobacco use trends among adolescents and adults in South Africa. J Psychol Afr 2008; 18:339-46. 
19. National Institutes of Health. Expert Panel Report 3. Guidelines for the diagnosis and management of asthma. NIH Publication No. 07-4051 Bethesda, MD: National Institutes of Health; 2007.

20. Van der Vaart H, Postma DS, et al. Acute effects of cigarette smoking on inflammation in healthy intermittent smokers. Respir Res 2005; 6: 22.

21. Behan DF, Michael P. Eriksen MP, Lin Y. Economic effects of Environmental Tobacco Smoke in 2005 Society of Actuaries. Available at http://erj.ersjournals.com. Last accessed November 2017.

22. Stapleton M, Howard-Thompson A, George C, Hoover RM, Self TH. Smoking and asthma. J Am Board Fam Med 2011; 24:313-22.

23. Boulet L-P, Lemière $C$, Archambault F,Carrier G, Claire MD, Deschesnes F. Smoking and asthma: clinical and radiologic features, lung function, and airway inflammation. Chest 2006; 129: 661-8.

24. Vanker A, Barnett W, Workman L, Nduru PM, Sly PD, Gie RP et al. Early-life exposure to indoor air pollution or tobacco smoke and lower respiratory tract illness and wheezing in African infants: a longitudinal birth cohort study. Lancet Planet Health 2017; 1: e328-36.

25. Wong GWK, Brunekreef B, Ellwood P, Anderson HR, Asher MI, Crane J et al. Cooking fuels and prevalence of asthma: a global analysis of phase three of the International Study of Asthma and Allergies in Childhood (ISAAC). The Lancet Respiratory Medicine 2013; 1:386-94, DOI: https://doi.org/10.1016/S2213-2600(13)70073-0

26. Oguonu T, Obumneme-Anyim IN, Eze JN, Ayuk AC, Okoli CV, Ndu IK. Prevalence and determinants of airflow limitation in urban and rural children exposed to cooking fuels in South-East Nigeria. Paediatr Int Child H 2018. Published online 15th March 2018. https://doi.org/10.1080/20469047.2018.1445506. 
27. Okada H, Kuhn C, Feillet H, Bach J-F. The 'hygiene hypothesis' for autoimmune and allergic diseases: an update. Clin Exp Immunol 2010; 160: 1-9.

28. Cullinan P. Childhood allergies, birth order and family size. Thorax 2006; 61:3-5.

29. Strachan DP, Aït-Khaled N, Foliaki S, Mallol J, Odhiambo J, Pearce, N et al. Siblings, asthma, rhinoconjunctivitis and eczema: a worldwide perspective from the International Study of Asthma and Allergies in Childhood. Clin Exp Allergy 2015; 45:126-36.

30. Goldberg S, Israeli E, Schwartz S, Shochat T, Izbicki G, Toker-Maimon O Klement E, Picard E. Asthma prevalence, family size, and birth order. Chest 2007,131:1747-52.

31. Steinman HA, Donson HA Kawalski M, Toerien A, Potter PC. Bronchial hyperresponsiveness and atopy in urban, peri-urban and rural South African children. Pediatr Allergy Imminol 2003; 14:383-93.

32. Vlaski E, Stavric K, Seckova L, Kimovska M, Isjanovska R. Influence of physical activity and television-watching time on asthma and allergic rhinitis among young adolescents: preventive or aggravating? Allergologia et Immunopathologia, 2008; 36;5 247- 53.

33. Anderson SD. How does exercise cause asthma attacks? Curr Opin Allergy Clin Immunol 2006: 6:37-42.

34. Shaheen SO, Newson RB, Smith GD, Henderson AJ, Stratton FD, Jones RW, Strachan DP and the ALSPAC Study Team. Prenatal paracetamol exposure and risk of asthma and elevated immunoglobulin E in childhood. Clin Exp Allergy 2005; 35: 18-25.

35. Shaheen SO, Newson RB, Sherriff A, Henderson AJ, J E Heron JE, Burney PGJ, J Golding J and the ALSPAC Study Team. Paracetamol use in pregnancy and wheezing in early childhood. Thorax 2002; 57: 958-63.

36. Oshnouei S, Salarilak Sh, Khalkhali A, Karamyar M, Rahimi R, Delpishe A. Effects of Acetaminophen consumption in asthmatic children. Iran Red Crescent Med J 2012; 14:641-6. 
37. Davey G, Berhane Y, Duncan P, Aref-Adib G, Britton J, Venn A. Use of acetaminophen and the risk of self-reported allergic symptoms and skin sensitization in Butajira, Ethiopia. J Allergy Clin Immunol 2005; 116: 863-8.

38. Beasley R, Clayton T, Crane J, von Mutius E, Lai CKW, Montefort S, Stewart A, for the ISAAC Phase Three Study Group. Association between paracetamol use in infancy and childhood, and risk of asthma, rhinoconjunctivitis, and eczema in children aged 6-7 years: analysis from Phase Three of the ISAAC programme. Lancet 2008; 372: 1039-48.

39. Beier J, Beeh KM, Semmler D, Beike N. Increased concentrations of glutathione in induced sputum of patients with mild or moderate allergic asthma. Annals of Allergy 2004; 92: 459-63.

40. Dimova, S, Hoet, PHM, Dinsdale, D, Nemery, B. Acetaminophen decreases intracellular glutathione levels and modulates cytokine production in human alveolar macrophages and type II pneumocytes in vitro. Int J Biochem Cell Biol. 2005; 37:1727-37. 


\section{FIGURES}

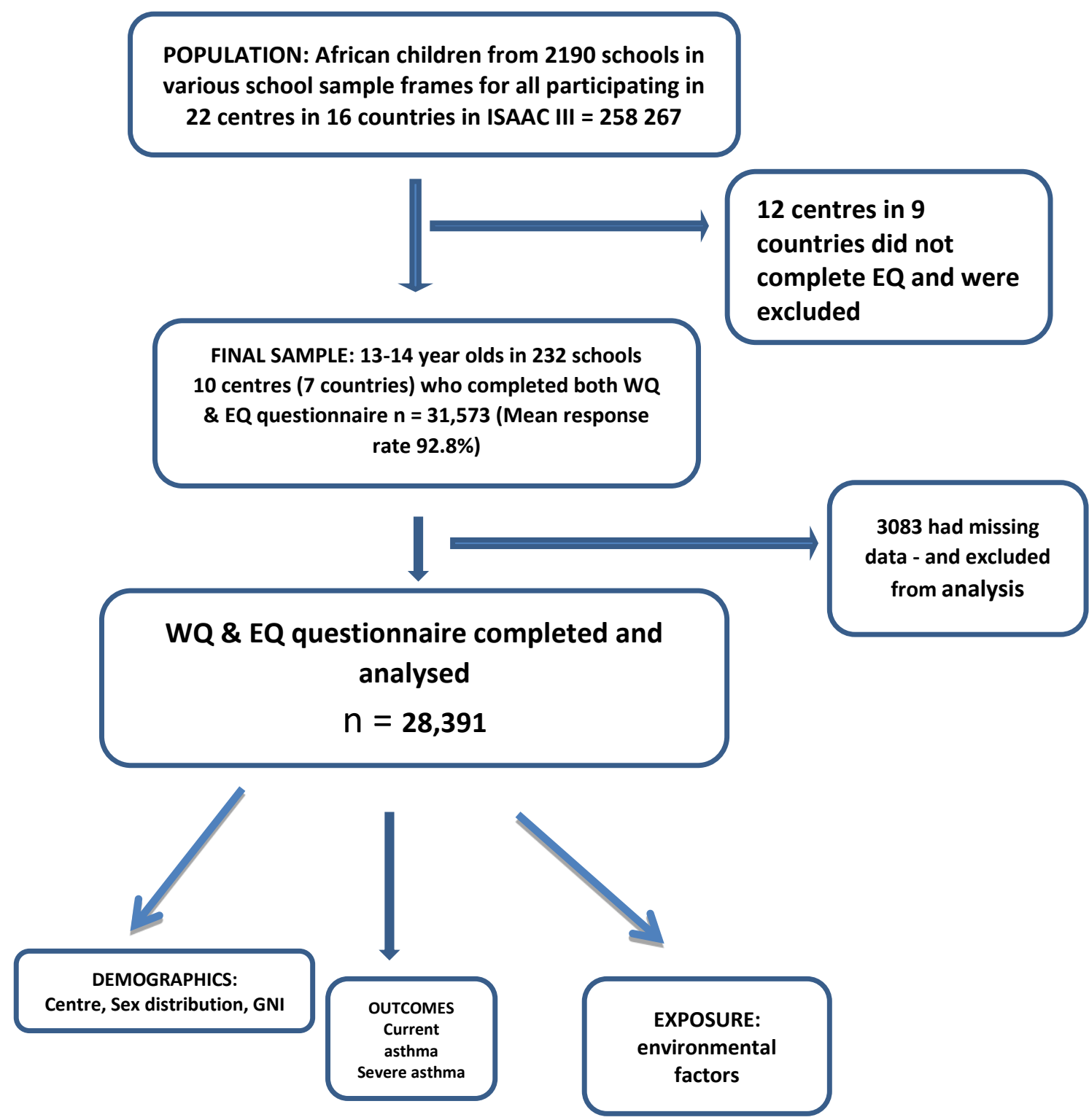

Figure 1: Flow chart for selection of adolescent participants in the environmental ISAAC III study for African centres 
Environmental risk factors for asthma in 13-14 year old African children

MPhil A Ayuk 2018

TABLES

Table 1: Characteristics of Participants in African centres in ISAAC III

\begin{tabular}{|c|c|c|c|c|c|c|c|c|c|c|}
\hline Centre & $\begin{array}{c}\text { Cape } \\
\text { Town } \\
\text { [SOUTH } \\
\text { AFRICA] }\end{array}$ & $\begin{array}{c}\text { Ibadan } \\
\text { [NIGERIA } \\
\text { ] }\end{array}$ & $\begin{array}{c}\text { Addis } \\
\text { Ababa } \\
\text { [ETHIOPI } \\
\text { A] }\end{array}$ & $\begin{array}{c}\text { Yaoundé } \\
\text { [CAMERO } \\
\text { UN] }\end{array}$ & $\begin{array}{c}\text { Urban } \\
\text { Cote } \\
\text { d'Ivoire } \\
\text { [COTE } \\
\text { DívOIRE] }\end{array}$ & $\begin{array}{c}\text { Port- } \\
\text { Gentil } \\
\text { [GABON] }\end{array}$ & $\begin{array}{c}\text { Boulmene } \\
\text { [MORROC } \\
\text { CO] }\end{array}$ & $\begin{array}{c}\text { Casablanc } \\
\text { a } \\
\text { [MORROC } \\
\text { CO] }\end{array}$ & $\begin{array}{c}\text { Marrakech } \\
\text { [MORROC } \\
\text { CO] }\end{array}$ & $\begin{array}{c}\text { Khartoum } \\
\text { [SUDAN] }\end{array}$ \\
\hline $\begin{array}{l}\text { Number } \\
\text { of } \\
\text { Participa } \\
\text { nts }\end{array}$ & 5037 & 3142 & 3195 & 2983 & 3342 & 3166 & 1254 & 1777 & 1689 & 2896 \\
\hline $\begin{array}{l}\text { Language } \\
\text { divide }\end{array}$ & $\begin{array}{l}\text { Anglopho } \\
\text { ne }\end{array}$ & $\begin{array}{l}\text { Anglopho } \\
\text { ne }\end{array}$ & $\begin{array}{l}\text { Anglopho } \\
\text { ne }\end{array}$ & $\begin{array}{l}\text { Francopho } \\
\text { ne }\end{array}$ & $\begin{array}{c}\text { Francoph } \\
\text { one }\end{array}$ & $\begin{array}{l}\text { Francoph } \\
\text { one }\end{array}$ & $\begin{array}{l}\text { Francopho } \\
\text { ne }\end{array}$ & $\begin{array}{l}\text { Francopho } \\
\text { ne }\end{array}$ & $\begin{array}{l}\text { Francopho } \\
\text { ne }\end{array}$ & $\begin{array}{l}\text { Francoph } \\
\text { one }\end{array}$ \\
\hline $\begin{array}{l}\text { Gender } \\
\text { (Male \%) }\end{array}$ & 40 & 57 & 43 & 46 & 60 & 47 & 60 & 52 & 42 & 53 \\
\hline $\begin{array}{l}\text { GNI gross } \\
\text { national } \\
\text { income }\end{array}$ & Middle & Low & Low & Low & Low & Low & Middle & Middle & Middle & Low \\
\hline $\begin{array}{l}\text { Response } \\
\text { rate (\%) }\end{array}$ & 83.4 & 99.7 & 96.8 & 90.6 & 82.5 & 78.7 & 100 & 100 & 99.9 & 96.5 \\
\hline
\end{tabular}


Environmental risk factors for asthma in 13-14 year old African children

MPhil A Ayuk 2018

Table 2: Prevalence rates of asthma in adolescents in African centres in ISAAC III

\begin{tabular}{|c|c|c|c|c|c|c|c|c|c|c|}
\hline Centre & $\begin{array}{c}\text { Cape } \\
\text { Town } \\
\text { [SOUTH } \\
\text { AFRICA] }\end{array}$ & $\begin{array}{l}\text { Ibadan } \\
\text { [NIGERIA } \\
\text { ] }\end{array}$ & $\begin{array}{c}\text { Addis } \\
\text { Ababa } \\
\text { [ETHIOPIA } \\
\text { ] }\end{array}$ & $\begin{array}{l}\text { Yaoundé } \\
\text { [CAMEROU } \\
\text { N] }\end{array}$ & $\begin{array}{c}\text { Urban } \\
\text { Cote } \\
\text { d'Ivoire } \\
\text { [COTE } \\
\text { DívoIRE } \\
\text { ] }\end{array}$ & $\begin{array}{c}\text { Port- } \\
\text { Gentil } \\
\text { [GABON } \\
\text { ] }\end{array}$ & $\begin{array}{c}\text { Boulmene } \\
\text { [MORROCC } \\
\text { o] }\end{array}$ & $\begin{array}{l}\text { Casablanca } \\
\text { [MORROCC } \\
\text { ] }\end{array}$ & $\begin{array}{l}\text { Marrakech } \\
\text { [MORROCC } \\
\text { o] }\end{array}$ & $\begin{array}{l}\text { Khartou } \\
\mathrm{m} \\
\text { [SUDAN] }\end{array}$ \\
\hline $\begin{array}{l}\text { Current } \\
\text { asthma \% } \\
(95 \% \mathrm{Cl})\end{array}$ & $\begin{array}{r}20.4 \\
(19.3- \\
21.5)\end{array}$ & $\begin{array}{r}13.0 \\
(11.8- \\
14.2)\end{array}$ & $\begin{array}{c}9.1 \\
(8.1- \\
10.1)\end{array}$ & $\begin{array}{c}\mathbf{5 . 7} \\
(4.9-6.6)\end{array}$ & $\begin{array}{r}19.3 \\
(18.0- \\
20.7)\end{array}$ & $\begin{array}{l}10.2 \\
(9.2- \\
11.3)\end{array}$ & $\begin{array}{c}5.4 \quad(4.2- \\
6.8)\end{array}$ & $\begin{array}{ll}16.0 & (14.4- \\
17.8) & \end{array}$ & $\begin{array}{l}4.4 \text { (3.5- } \\
5.5)\end{array}$ & $\begin{array}{c}12.5 \\
(11.3- \\
13.7)\end{array}$ \\
\hline $\mathrm{n} / \mathrm{N}^{*}$ & $\begin{array}{c}1025 / 503 \\
7\end{array}$ & $\begin{array}{c}408 / 314 \\
9\end{array}$ & $290 / 3195$ & $169 / 2983$ & $645 / 3342$ & $324 / 3168$ & $68 / 1254$ & $285 / 1777$ & $75 / 1689$ & $361 / 2876$ \\
\hline $\begin{array}{l}\text { Severe } \\
\text { asthma/Total } \\
(\%) \\
(95 \% \mathrm{Cl})\end{array}$ & $\begin{array}{r}12.4 \\
{[11.5-} \\
13.3]\end{array}$ & $\begin{array}{c}9.5 \\
{[8.5-} \\
10.6]\end{array}$ & $\begin{array}{c}8.2 \\
{[7.3-9.2]}\end{array}$ & $\begin{array}{c}4.3 \\
{[3.6-5.1]}\end{array}$ & $\begin{array}{r}12.0 \\
{[10.9-} \\
13.1]\end{array}$ & $\begin{array}{c}5.9 \\
{[5.1-6.8]}\end{array}$ & $\begin{array}{c}2.7 \quad[1.9- \\
3.8]\end{array}$ & $\begin{array}{l}8.7 \\
10.1]\end{array}$ & $\begin{array}{c}2.2 \quad[1.6- \\
3.0]\end{array}$ & $\begin{array}{c}9.5 \\
{[8.5-} \\
10.6]\end{array}$ \\
\hline $\begin{array}{l}\text { Severe } \\
\text { asthma/current } \\
\text { asthma\% } \\
(\mathrm{n} / \mathrm{N}) * \dagger\end{array}$ & $\begin{array}{c}46.4 \\
(476 / 1025 \\
)\end{array}$ & $\begin{array}{c}39.2 \\
(132 / 337 \\
)\end{array}$ & $\begin{array}{c}63.8 \\
(185 / 290)\end{array}$ & $\begin{array}{c}47.3 \\
(80 / 169)\end{array}$ & $\begin{array}{c}61.9 \\
(399 / 645)\end{array}$ & $\begin{array}{c}44.1 \\
(143 / 324)\end{array}$ & $48.5 \quad(33 / 68)$ & $54.0(154 / 285)$ & $48.0 \quad(36 / 75)$ & $\begin{array}{c}58.2 \\
(210 / 361)\end{array}$ \\
\hline $\begin{array}{l}\text { Asthma } \\
\text { ever }\end{array}$ & 33.15 & 20.4 & 17.5 & 8.9 & 28.4 & 16.5 & 10.9 & 23.8 & 10.1 & 16.3 \\
\hline $\begin{array}{l}\text { Severe/asthm } \\
\text { a ever } \\
\text { proportion } \\
\text { (\%) }\end{array}$ & 32.6 & 10.3 & 46.8 & 36.4 & 42.19 .31 & 27.8 & 23.5 & 36.7 & 21.8 & 46.7 \\
\hline
\end{tabular}

*unweighted prevalence $\mathrm{t}$ proportion of severe asthma of those with current asthma 
Environmental risk factors for asthma in 13-14 year old African children

MPhil A Ayuk 2018

Table 3: Prevalence of environmental risk factors in Africa

\begin{tabular}{lll}
\hline Environmental factors (variables) & $\begin{array}{l}\text { All African centres combined } \\
\text { prevalence } \\
\mathbf{n}(\%)\end{array}$ & $\begin{array}{l}\text { Prevalence range of centres } \\
\text { (\%) }\end{array}$ \\
\hline Mom smokes & $1,959(6.9)$ & 0.5 to 27.9 \\
Dad smokes & $6,156(21.6)$ & 2.8 to 42.3 \\
$\geq 3$ Smokers at home & $15,371(54.0)$ & 14.8 to 100 \\
Electric cooking & $7327(25.7)$ & 0.5 to 88.1 \\
Gas cooking & $17967(63.1)$ & 10.0 to 97.6 \\
Fire cooking & $8051(28.3)$ & 0.1 to 85.8 \\
Electric heating & $7,394(26.0)$ & 0.00 to 70.3 \\
Gas heating & $3,333(11.7)$ & 0.00 to 27.7 \\
Fire heating & $6,472(22.7)$ & 0.03 to 88.2 \\
$\geq 2$ Older siblings & $24,378(85.6)$ & 69.6 to 99.9 \\
$\geq 2$ Younger siblings & $23,811(83.6)$ & 67.5 to 99.9 \\
Cat at home & $11,043(38.8)$ & 20.0 to 75.3 \\
Dog at home & $9,596(33.7)$ & 14.5 to 52.9 \\
$\geq 3$ weekly exercise & $5613(19.7)$ & 5.9 to 33.3 \\
$\geq 5$ television hours & $9603(33.7)$ & 17.1 to 58.9 \\
Monthly paracetamol & $11,654(40.9)$ & 16.4 to 64.3 \\
\hline
\end{tabular}


Environmental risk factors for asthma in 13-14 year old African children

MPhil A Ayuk 2018

Table 4: Environmental exposures and association with current asthma in African adolescents participating in ISAAC III

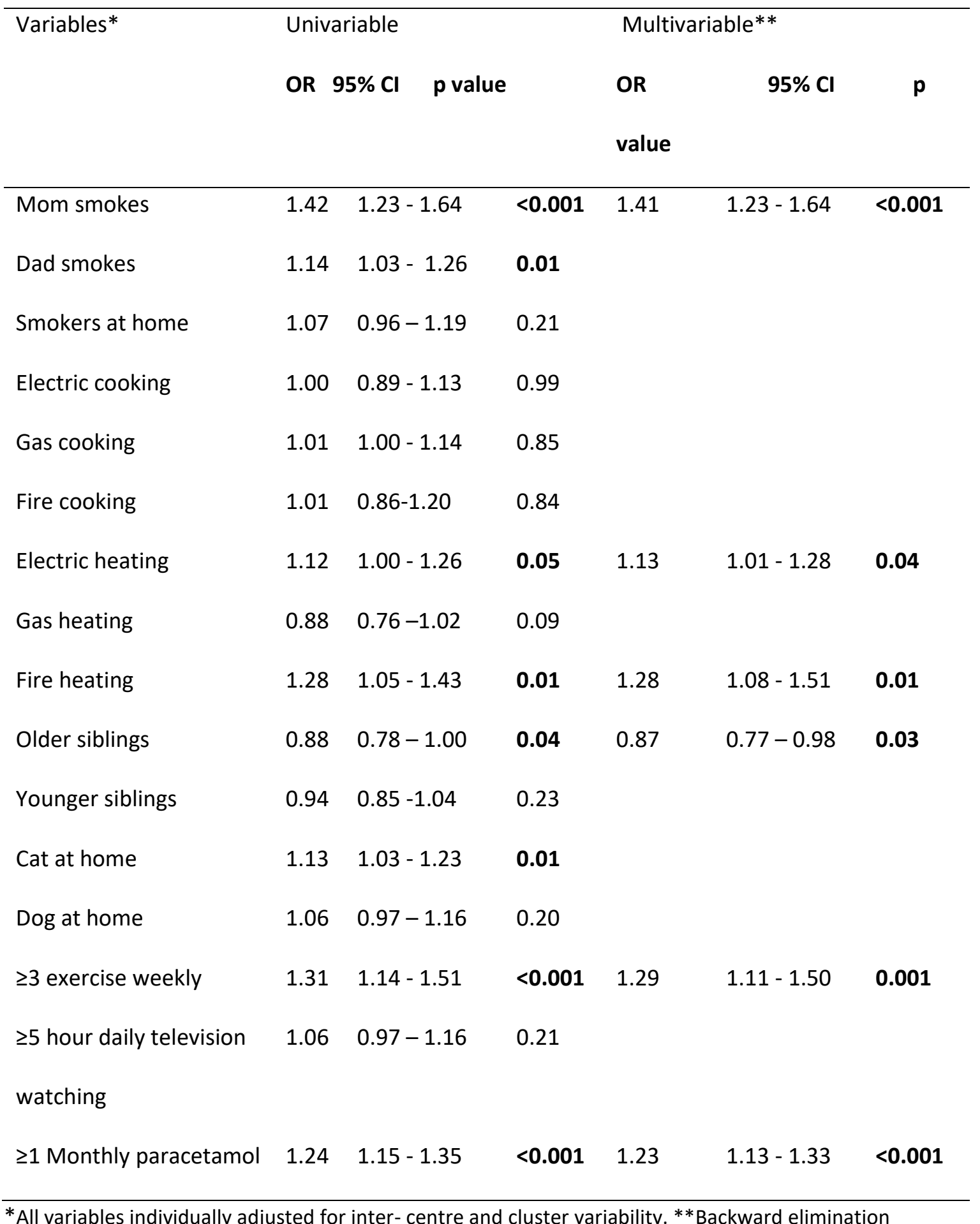


Environmental risk factors for asthma in 13-14 year old African children

MPhil A Ayuk 2018

Table 5: Environmental exposures and association with severe asthma in African adolescents participating in ISAAC III

\begin{tabular}{|c|c|c|c|c|c|c|}
\hline \multirow{3}{*}{$\begin{array}{l}\text { Variables* } \\
\text { Mom smokes }\end{array}$} & \multicolumn{3}{|c|}{ Univariable } & \multicolumn{3}{|c|}{ Multivariable } \\
\hline & \multirow{2}{*}{$\begin{array}{l}\text { OR } \\
1.63\end{array}$} & $95 \% \mathrm{Cl}$ & value & \multirow{2}{*}{$\begin{array}{c}\text { OR } \\
1.61\end{array}$} & \multirow{2}{*}{$\begin{array}{l}95 \% \mathrm{Cl} \\
1.38-1.89\end{array}$} & $p$ value \\
\hline & & $1.39-1.90$ & $<0.001$ & & & $<0.001$ \\
\hline Dad smokes & 1.15 & $1.03-1.29$ & 0.02 & & & \\
\hline Smokers at home & 1.17 & $1.03-1.34$ & 0.02 & & & \\
\hline Electric cooking & 1.03 & $0.82-1.28$ & 0.81 & & & \\
\hline Gas cooking & 1.07 & $0.93-1.23$ & 0.33 & & & \\
\hline Fire cooking & 1.07 & $0.91-1.26$ & 0.43 & & & \\
\hline Electric heating & 1.00 & $0.87-1.14$ & 0.99 & & & \\
\hline Gas heating & 1.02 & $0.89-1.17$ & 0.77 & & & \\
\hline Fire heating & 1.15 & $0.94-1.40$ & 0.17 & & & \\
\hline Older siblings & 0.95 & 0.83- 1.09 & 0.46 & & & \\
\hline Younger siblings & 1.07 & $0.94-1.20$ & 0.31 & & & \\
\hline Cat at home & 1.17 & $1.07-1.29$ & 0.001 & 1.14 & $1.04-1.25$ & 0.03 \\
\hline Dog at home & 1.11 & $1.00-1.24$ & 0.06 & & & \\
\hline$\geq 3$ weekly exercise & 1.42 & $1.23-1.63$ & $<0.001$ & 1.42 & $1.23-1.64$ & $<0.001$ \\
\hline$\geq 5$ hour daily television watching & 1.12 & $0.99-1.24$ & 0.07 & & & \\
\hline$\geq 1$ Monthly paracetamol & 1.21 & $1.09-1.36$ & 0.001 & 1.20 & $1.07-1.34$ & $<0.001$ \\
\hline
\end{tabular}

*All variables adjusted for inter- centre and cluster variability and **Backward elimination 
Environmental risk factors for asthma in 13-14 year old African children

MPhil A Ayuk 2018

**Supplementary tables: Environmental exposures and association with language (cultural) divide

Table 6: Environmental exposures and association with current asthma in Anglophone African adolescents participating in ISAAC III

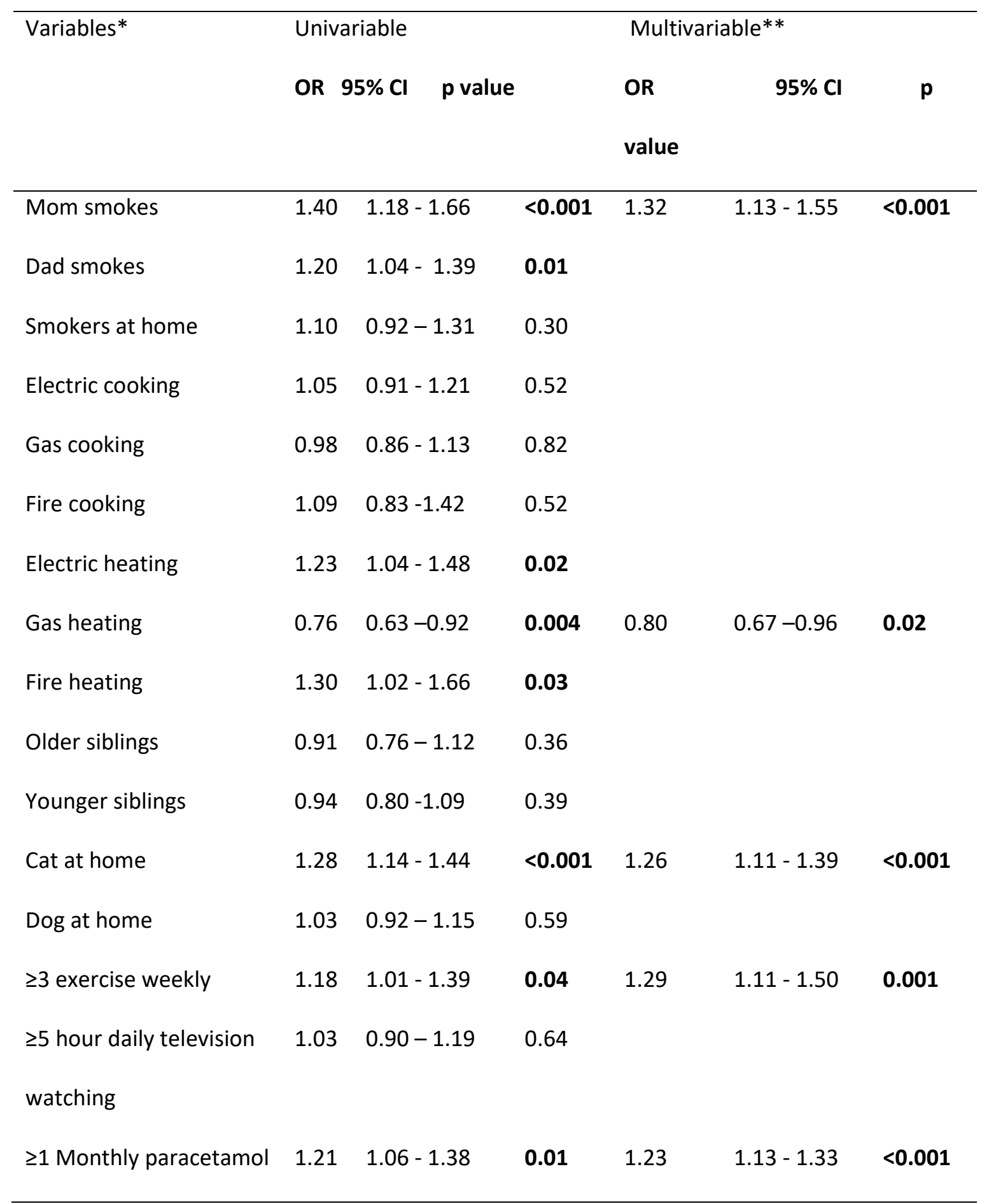

*All variables individually adjusted for inter- centre and cluster variability. ${ }^{* *}$ Backward elimination 
Environmental risk factors for asthma in 13-14 year old African children

MPhil A Ayuk 2018

Table 7: Environmental exposures and association with current asthma in Francophone African adolescents participating in ISAAC III

\begin{tabular}{|c|c|c|c|c|c|c|}
\hline \multirow{3}{*}{$\begin{array}{l}\text { Variables* } \\
\text { Mom smokes }\end{array}$} & \multicolumn{3}{|c|}{ Univariable } & \multicolumn{3}{|c|}{ Multivariable } \\
\hline & \multirow{2}{*}{$\begin{array}{l}\text { OR } \\
1.52\end{array}$} & $95 \% \mathrm{Cl}$ & value & \multirow{2}{*}{$\begin{array}{l}\text { OR } \\
1.47\end{array}$} & \multirow{2}{*}{$\begin{array}{l}95 \% \mathrm{Cl} \\
1.19-1.83\end{array}$} & p value \\
\hline & & $1.23-1.88$ & $<0.001$ & & & $<0.001$ \\
\hline Dad smokes & 1.09 & $0.95-1.24$ & 0.22 & & & \\
\hline Smokers at home & 1.06 & $0.92-1.21$ & 0.43 & & & \\
\hline Electric cooking & 0.90 & $0.71-1.15$ & 0.41 & & & \\
\hline Gas cooking & 1.05 & $0.85-1.29$ & 0.66 & & & \\
\hline Fire cooking & 0.96 & $0.78-1.18$ & 0.72 & & & \\
\hline Electric heating & 1.02 & $0.87-1.14$ & 0.99 & & & \\
\hline Gas heating & 1.18 & $1.00-1.40$ & 0.05 & 1.31 & $1.09-1.57$ & 0.003 \\
\hline Fire heating & 1.18 & $0.96-1.44$ & 0.12 & 1.25 & $1.01-1.56$ & 0.04 \\
\hline Older siblings & 0.95 & 0.83- 1.09 & 0.46 & & & \\
\hline Younger siblings & 0.95 & $0.83-1.08$ & 0.40 & & & \\
\hline Cat at home & 1.01 & $0.90-1.14$ & 0.83 & & & \\
\hline Dog at home & 1.09 & $0.95-1.26$ & 0.22 & & & \\
\hline$\geq 3$ weekly exercise & 1.46 & $1.16-1.83$ & 0.001 & 1.45 & $1.15-1.82$ & 0.002 \\
\hline$\geq 5$ hour television watching daily & 1.08 & $0.95-1.21$ & 0.22 & & & \\
\hline$\geq 1$ Monthly paracetamol & 1.27 & $1.15-1.41$ & $<0.001$ & 1.27 & $1.19-1.83$ & $<0.001$ \\
\hline
\end{tabular}

*All variables adjusted for inter- centre and cluster variability and **Backward elimination 
Environmental risk factors for asthma in 13-14 year old African children

MPhil A Ayuk 2018

Table 8: Environmental exposures and association with severe asthma in Anglophone African adolescents participating in ISAAC III

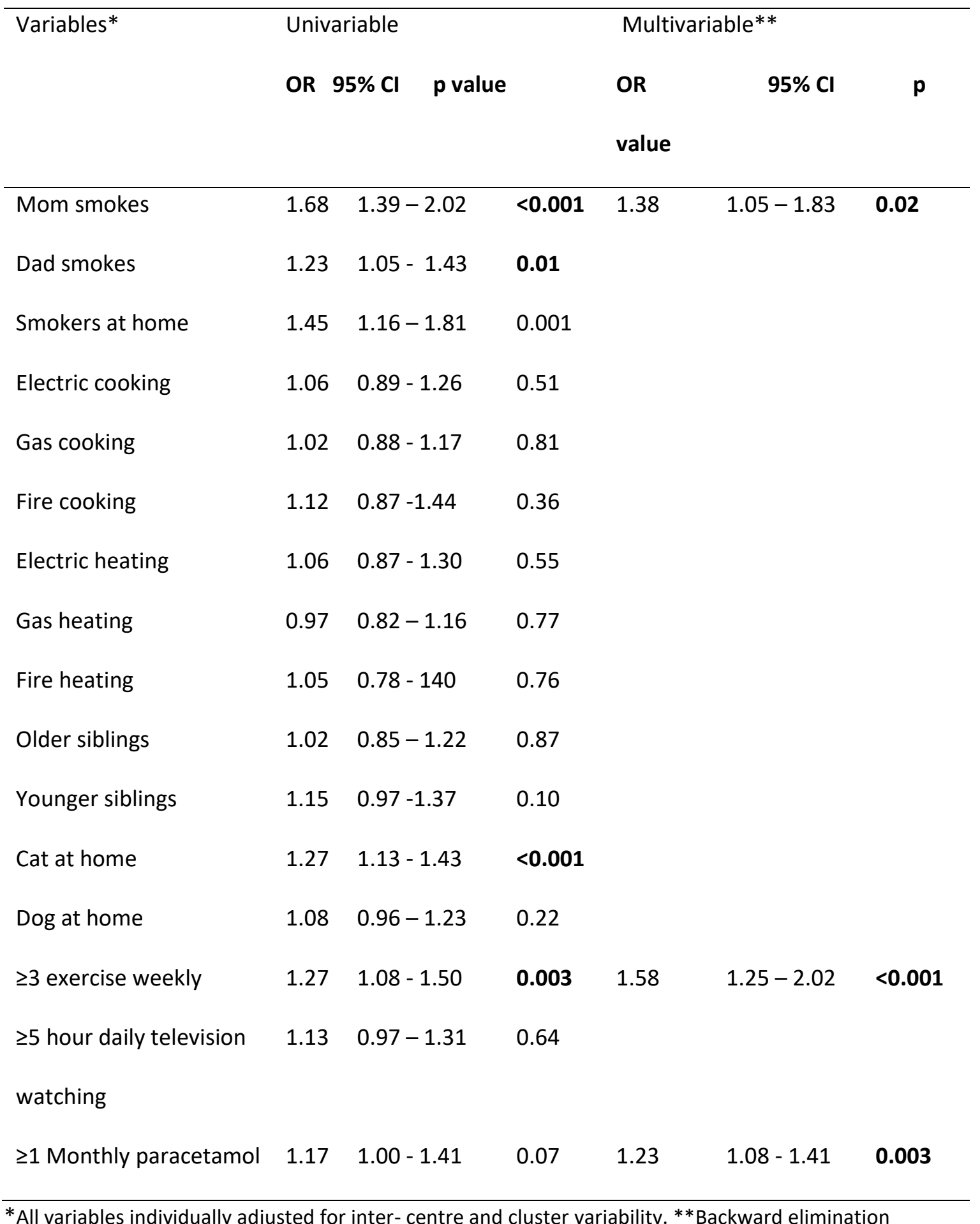


Environmental risk factors for asthma in 13-14 year old African children

MPhil A Ayuk 2018

Table 9: Environmental exposures and association with severe asthma in Francophone African adolescents participating in ISAAC III

\begin{tabular}{|c|c|c|c|c|c|c|}
\hline \multirow{3}{*}{$\begin{array}{l}\text { Variables* } \\
\text { Mom smokes }\end{array}$} & \multicolumn{3}{|c|}{ Univariable } & \multicolumn{3}{|c|}{ Multivariable } \\
\hline & \multirow{2}{*}{$\begin{array}{c}\text { OR } \\
1.46\end{array}$} & $95 \% \mathrm{Cl}$ & value & \multirow{2}{*}{$\begin{array}{l}\text { OR } \\
1.38\end{array}$} & $95 \% \mathrm{Cl}$ & value \\
\hline & & $1.10-1.92$ & 0.01 & & $1.05-1.83$ & 0.02 \\
\hline Dad smokes & 1.09 & $0.92-1.29$ & 0.34 & & & \\
\hline Smokers at home & 1.04 & $0.89-1.21$ & 0.65 & & & \\
\hline Electric cooking & 1.00 & $0.75-1.34$ & 0.99 & & & \\
\hline Gas cooking & 1.16 & $0.87-1.56$ & 0.31 & & & \\
\hline Fire cooking & 1.02 & $0.82-1.27$ & 0.86 & & & \\
\hline Electric heating & 0.93 & $0.78-1.11$ & 0.43 & & & \\
\hline Gas heating & 1.14 & $0.93-1.40$ & 0.22 & & & \\
\hline Fire heating & 1.24 & $0.94-1.62$ & 0.12 & & & \\
\hline Older siblings & 0.90 & $0.74-1.10$ & 0.29 & & & \\
\hline Younger siblings & 0.99 & $0.83-1.18$ & 0.919 & & & \\
\hline Cat at home & 1.01 & $0.95-1.24$ & 0.24 & & & \\
\hline Dog at home & 1.15 & $0.95-1.41$ & 0.12 & & & \\
\hline$\geq 3$ weekly exercise & 1.61 & $1.27-2.04$ & 0.001 & 1.59 & $1.25-2.02$ & $<0.001$ \\
\hline$\geq 5$ hour television watching daily & 1.09 & $0.93-1.27$ & 0.29 & & & \\
\hline$\geq 1$ Monthly paracetamol & 1.25 & $1.09-1.43$ & 0.001 & 1.23 & $1.08-1.41$ & 0.003 \\
\hline
\end{tabular}

*All variables adjusted for inter- centre and cluster variability and **Backward elimination

*All variables adjusted for inter- centre and cluster variability and **Backward elimination 
Environmental risk factors for asthma in 13-14 year old African children

MPhil A Ayuk 2018

\section{CHAPTER 3}

\section{APPENDICES}

\section{Appendix 1}

\section{Approval of protocol}

Questionnaire/data capture instrument(s) • Consent forms and related participant information sheets - Technical appendices and relevant additional tables not included in the main manuscript. These should be accompanied by a brief narrative. • Ethics approval letters (except for a full systematic review) and other relevant permissions • Instructions to authors if format I or II is submitted 


\section{APPENDICES}

\section{JOURNAL AUTHOR GUIDELINES}

Pediatric Pulmonology

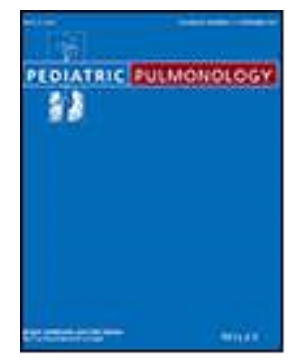

(c) Wiley Periodicals, Inc.

Edited By: Thomas Murphy

Impact Factor: 2.758

ISI Journal Citation Reports (C) Ranking: 2016: 19/121 (Pediatrics); 26/59 (Respiratory System) Online ISSN: 1099-0496

Author Guidelines

(http://onlinelibrary.wiley.com/journal/10.1002/(ISSN)1099-

0496/homepage/ForAuthors.html\#banner)

-SCOPE OF JOURNAL (http://onlinelibrary.wiley.com/journal/10.1002/(ISSN)10990496/homepage/ForAuthors.html\#1s0)

- PERMISSIONS (http://onlinelibrary.wiley.com/journal/10.1002/(ISSN)10990496/homepage/ForAuthors.html\#2s0)

-AUTHOR RESOURCES (http://onlinelibrary.wiley.com/journal/10.1002/(ISSN)10990496/homepage/ForAuthors.html\#3s0)

-ENGLISH LANGUAGE SERVICES (http://onlinelibrary.wiley.com/journal/10.1002/(ISSN)10990496/homepage/ForAuthors.html\#4s0)

- ELECTRONIC SUBMISSION OF MANUSCRIPTS (http://onlinelibrary.wiley.com/journal/10.1002/(ISSN)10990496/homepage/ForAuthors.html\#5s0)

-MANUSCRIPT GUIDELINES (http://onlinelibrary.wiley.com/journal/10.1002/(ISSN) 10990496/homepage/ForAuthors.html\#6s0)

- Original Research Articles (http://onlinelibrary.wiley.com/journal/10.1002/(ISSN) 10990496/homepage/ForAuthors.html\#Original)

- Reviews/State of the Art Papers (http://onlinelibrary.wiley.com/journal/10.1002/(ISSN)10990496/homepage/ForAuthors.html\#Reviews) 
- Case Reports (http://onlinelibrary.wiley.com/journal/10.1002/(ISSN)10990496/homepage/ForAuthors.html\#Case)

- Editorials (Commentaries) (http://onlinelibrary.wiley.com/journal/10.1002/(ISSN) 10990496/homepage/ForAuthors.html\#Editorials)

- Letters to the Editor (http://onlinelibrary.wiley.com/journal/10.1002/(ISSN)10990496/homepage/ForAuthors.html\#Letters to the Editor)

-PRIOR TO SUBMITTING (http://onlinelibrary.wiley.com/journal/10.1002/(ISSN)10990496/homepage/ForAuthors.html\#7s0)

- COMPONENTS OF ARTICLES/FILE PREPARATION

(http://onlinelibrary.wiley.com/journal/10.1002/(ISSN)1099-

0496/homepage/ForAuthors.html\#8s0)

- Main Document (http://onlinelibrary.wiley.com/journal/10.1002/(ISSN)1099-

0496/homepage/ForAuthors.html\#Main Doc)

-Title Page

Summary/Abstract

Acknowledgements

Informed Consent

References

Keywords

Abbreviations

Drug Names

Eponyms

Formatting Specific to Original Research Articles

-Tables (http://onlinelibrary.wiley.com/journal/10.1002/(ISSN)1099-

0496/homepage/ForAuthors.html\#Tables)

-Images (http://onlinelibrary.wiley.com/journal/10.1002/(ISSN)1099-

0496/homepage/ForAuthors.html\#Images)

- Online Supporting Information (http://onlinelibrary.wiley.com/journal/10.1002/(ISSN)1099-

0496/homepage/ForAuthors.html\#Supporting)

- POLICIES/DISCLOSURE STATEMENTS (http://onlinelibrary.wiley.com/journal/10.1002/(ISSN)10990496/homepage/ForAuthors.html\#9s0)

- Conflict of Interest (http://onlinelibrary.wiley.com/journal/10.1002/(ISSN)10990496/homepage/ForAuthors.html\#COI)

- Experimental and Publication Ethics (http://onlinelibrary.wiley.com/journal/10.1002/(ISSN)10990496/homepage/ForAuthors.html\#Ethics)

- Plagiarism (http://onlinelibrary.wiley.com/journal/10.1002/(ISSN)10990496/homepage/ForAuthors.html\#Plagiarism)

- Prior Publication (http://onlinelibrary.wiley.com/journal/10.1002/(ISSN)10990496/homepage/ForAuthors.htm|\#Prior Publication)

- Clinical Trials (http://onlinelibrary.wiley.com/journal/10.1002/(ISSN)10990496/homepage/ForAuthors.html\#Clinical Trials) 
-PEER REVIEW PROCESS (http://onlinelibrary.wiley.com/journal/10.1002/(ISSN) 10990496/homepage/ForAuthors.html\#10s0)

-FAST TRACK REVIEW (http://onlinelibrary.wiley.com/journal/10.1002/(ISSN)10990496/homepage/ForAuthors.html\#11s0)

-SUBMISSIONS FROM EDITORS AND EDITORIAL BOARD MEMBERS (http://onlinelibrary.wiley.com/journal/10.1002/(ISSN)10990496/homepage/ForAuthors.html\#12s0)

-AUTHOR CHARGES (http://onlinelibrary.wiley.com/journal/10.1002/(ISSN)10990496/homepage/ForAuthors.html\#13s0)

- MANUSCRIPTS ACCEPTED FOR PUBLICATION

(http://onlinelibrary.wiley.com/journal/10.1002/(ISSN)10990496/homepage/ForAuthors.htm|\#14s0)

- Online Open (http://onlinelibrary.wiley.com/journal/10.1002/(ISSN)10990496/homepage/ForAuthors.html\#Online_Open)

- Copyright Transfer Agreement (http://onlinelibrary.wiley.com/journal/10.1002/(ISSN)10990496/homepage/ForAuthors.html\#Copyright_Transfer)

-PROOFS (http://onlinelibrary.wiley.com/journal/10.1002/(ISSN)10990496/homepage/ForAuthors.html\#15s0)

-REPRINTS (http://onlinelibrary.wiley.com/journal/10.1002/(ISSN)10990496/homepage/ForAuthors.html\#16s0)

-APPEALS PROCESS (http://onlinelibrary.wiley.com/journal/10.1002/(ISSN)10990496/homepage/ForAuthors.html\#17s0)

-PRODUCTION QUESTIONS (http://onlinelibrary.wiley.com/journal/10.1002/(ISSN) 10990496/homepage/ForAuthors.html\#18s0)

- QUESTIONS ABOUT YOUR SUBMISSION (http://onlinelibrary.wiley.com/journal/10.1002/(ISSN)10990496/homepage/ForAuthors.html\#19s0)

-CONTACT THE EDITOR-IN-CHIEF (http://onlinelibrary.wiley.com/journal/10.1002/ (ISSN)10990496/homepage/ForAuthors.html\#20s0)

SCOPE OF JOURNAL

Pediatric Pulmonology publishes the results of original clinical or laboratory research, state of the art reviews, exceptionally instructive or unique case reports, and letters to the Editor (and responses), pertaining to the specialty.

Reports on meetings, conferences and symposia may be published after consultation with the Publisher and the Editor-in-Chief.

Preliminary brief communications will be considered if the articles contain information which would be considered a major breakthrough in the field.

We do not publish research funded by tobacco companies.

As the field is continually evolving, our Journal has seen an increase in the number of submissions over the past few years, and, as a result, our rejection rate is climbing. 
Environmental risk factors for asthma in 13-14 year old African children

MPhil A Ayuk 2018

\section{PERMISSIONS}

No material published in Pediatric Pulmonology may be reproduced or published elsewhere without the written permission of the publisher and the author. To request permission to reproduce an article, in part, or in whole, click here to for the Permissions Page (http://onlinelibrary.wiley.com/journal/10.1002/(ISSN)10990496/homepage/Permissions.html)

\section{AUTHOR RESOURCES}

For additional tools visit Author Services (http://authorservices.wiley.com/bauthor/default.asp) - an enhanced suite of online tools for WileyOnlineLibary journal authors, featuring Article Tracking, E-mail Publication Alerts and Customized Research Tools.

\section{ENGLISH LANGUAGE SERVICES}

The Editors reserve the right to return any manuscript that is not in acceptable English. Translations from another language will not be provided by the Editorial Office. Authors from countries in which English is not the primary language should have their manuscript reviewed and corrected by an English language service before submission. To read more about our policy, and to view a list of editing services, visit:

http://authorservices.wiley.com/bauthor/english language.asp (http://authorservices.wiley.com/bauthor/english language.asp)

\section{GUIDELINES FOR COVER SUBMISSIONS}

If you would like to send suggestions for artwork related to your manuscript to be considered to appear on the cover of the journal, please follow these general guidelines.

(http://olabout.wiley.com/WileyCDA/Section/id-828302.html)

\section{ELECTRONIC SUBMISSION OF MANUSCRIPTS}

If you are familiar with our guidelines, click here (http://mc.manuscriptcentral.com/ppul) to login to your ScholarOne account to submit your manuscript. If you do not have an account, click on "Register Here" to establish one.

\section{MANUSCRIPT GUIDELINES}

We accept submissions of the following types of articles. Please note the specific guidelines for each type:

\section{Original Research Articles}

Original Research Articles should follow the standard structure of abstract, introduction, methods, results, discussion, and references, and may include up to six tables and/or images when appropriate. Original Research Articles should be limited to 3,500 words (not including the abstract or references). The abstract should not exceed 250 words, and references should be limited to forty (40).

\section{Reviews/State of the Art Papers}

Editors generally commission Reviews and State of the Art papers, but uninvited submissions are also welcome, particularly if the submission outlines an important and topical subject with a focus on recent advances. Reviews should be limited to 4,000 words, while State of the Art papers should be limited to 5,000 words (not including the abstract or references). We ask that the abstracts for these manuscript types do not exceed 250 words. There is no set limit on images, tables, or references for these types of manuscripts. 
Environmental risk factors for asthma in 13-14 year old African children

MPhil A Ayuk 2018

Case Reports

NOTICE TO AUTHORS OF CASE REPORTS: Pediatric Pulmonology is temporarily closing submissions of Case Reports. We will not consider new case report manuscripts during the period of July 15, 2017 to October 15, 2017. Case Report submission will re-open on October 15, 2017.

Pediatric Pulmonology will review case report manuscripts that present unique, paradigmchanging, or novel accounts of infantile or childhood disorders. Priority for selection for publication will be given to the following categories:.

1.Novel therapies and outcomes for cystic fibrosis

2.Novel disorders or outcomes of ChILD, NEHI, ABCA3 disorders, and surfactant disorders

3.Novel congenital malformations

4.Novel genetic disorders

5.Novel therapies or outcomes for other disorders

There is not a related format for a case series. Manuscripts of this nature will be treated as original articles or reviews and will compete with other manuscripts in these categories. Case reports should be concise (a maximum of 1,000 words, not including the abstract or references), and contain a maximum of two images and/or tables. The summary/abstract should not exceed 100 words. Case Reports should contain no more than five (5) references. Authorship of case reports shall be limited to three (3). Physicians who participated in the care, but did not contribute to the writing of the manuscript may be listed under acknowledgements. Informed consent must be documented. Authors should note that most accepted Case Reports will be published online only, and not in a print edition.

Editorials (Commentaries)

Editors and members of the Editorial Board may make editorial comments on individual articles or on a group of articles published in the same issue. Editorials (including pro/con debates) from authors who are not part of the editorial team are also welcome as submissions to the Journal. These narrowly focused articles should discuss an article that was recently published, or that is soon to be published. The commentary should discuss specific issues within a subject area rather than the whole field, while explaining the implications of the article and putting it in context. Opinions must be factually based. These types of manuscripts should be limited to 1,500 words (not including the abstract or references). There is no limitation on the number of tables, images or references for these types of manuscripts.

\section{Letters to the Editors}

We encourage letters that offer criticism of published material in an objective, constructive, and educational manner conducive to further exchanges. Such letters will only be considered if they are in reference to an article published within the previous six months. Letters may also discuss matters of general interest pertaining to the field of pediatric pulmonology, or may consist of brief reports of truly unique cases. Note that we do not publish original, previously unpublished data as letters. If appropriate, a copy will be sent to the author(s) referred to in the letter, so that they may respond. Letters to the Editor should not exceed 1,000 words (not including the abstract or references), and may contain a small table or single image. Letters should contain no more than five (5) references.

Top of Page (http://onlinelibrary.wiley.com/journal/10.1002/(ISSN)1099-

0496/homepage/ForAuthors.html\#banner)

\section{PRIOR TO SUBMITTING}


Prior to submitting a manuscript through ScholarOne (http://mc.manuscriptcentral.com/ppul), prepare the text and images according to the instructions found below. You may enter and exit the manuscript submission process at the completion of each step, and you may save an unfinished draft in the system to work on later. However, once you submit your manuscript though the system, you will not be able to access it for editing. If you have any questions about this process please contact us at edsupport@ wiley.com(mailto:edsupport@ wiley.com)

We recommend all authors familiarize themselves with the International Committee of Medical Journal Editors: Uniform Requirements for Manuscripts submitted to Biomedical Journals. Ann Intern Med 1997;126:36-47. The complete text of the document be found online at www.icmje.org (http://www.icmje.org/)

\section{COMPONENTS OF ARTICLES/FILE PREPARATION}

Please make note of the following when preparing your submission:

\section{Main Document}

All manuscript types must include a title page, abstract, text and references in the Main Document. Standard, double-spaced manuscript format, in 12 point font is requested. Number all pages consecutively.

Title page: The title should be brief (no more than 100 characters in length including spaces) and useful for indexing. All authors' names with highest academic degree, affiliation of each, but no position or rank, should be listed. For cooperative studies, the institution where research was primarily done should be indicated. In a separate paragraph, specify grants, other financial support received, and the granting institutions (grant number(s) and contact name(s) should be indicated on the title page). If support from manufacturers of products used is listed, assurances about the absence of bias by the sponsor and principal author must be given. Identify meetings, if any, at which the paper was presented. The name, complete mailing address, telephone number, fax number, and e-mail address of the person to whom correspondence and reprint requests are to be sent must be included. Keywords should also be noted on the title page. For usage as a running head, provide an abbreviated title (maximum 50 characters) on the bottom of the title page.

Summary/Abstract: In accordance with the structure of the article, with or without separate headings, outline the objectives, working hypothesis, study design, patient-subject selection, methodology, results (including numerical findings) and conclusions. The Summary should not exceed the word counts outlined above. If abbreviations are used several times, spell out the words followed by the abbreviations in parentheses.

Acknowledgements: Technical assistance, advice, referral of patients, etc. may be briefly acknowledged at the end of the text under "Acknowledgements."

Informed Consent: Informed consent statements, if applicable, should be included in the Methods section.

References/citations: References may be included at the end of your text, or uploaded as a separate file. Ensure your references are up to date, and include a critical selection from the world literature. References should be prepared according to CSE (Council of Science Editors) citation-sequence style. Refer to the Scientific Style and Format: The CSE Manual for Authors, Editors, and Publishers, 8th edition (University of Chicago Press). Start the listing on a new page, double-spaced throughout. 
Number the references in the sequence in which they first appear in the text, listing each only once even though it may be cited repeatedly.

When citing a reference in the text, the style advocated by CSE suggests numbers appear in superscript, and appear before punctuation marks (commas or periods). In the citationsequence system, sources are numbered by order of reference so that the first reference cited in the paper is 1 , the second 2 , and so on. If the numbers are not in a continuous sequence, use commas (with no spaces) between numbers. If you have more than two numbers in a continuous sequence, use the first and last number of the sequence joined by a hyphen, for example 2,4,6-10.

In the references, list the first ten authors of the cited paper. If there are more than ten authors, list the first 10 authors followed by ' et al' .

Journals' names should be shown by their abbreviated title in Index Medicus.

Manuscripts in preparation or submitted for publication are not acceptable references. If a manuscript "in press" is used as a reference, a copy of it must be provided with your submission.

Sample references:

Standard journal article

Landau IL, Morgan W, McCoy KS, Taussig LM. Gender related differences in airway tone in children. Pediatr Pulmonol 1993;16:31-35.

Book with authors

Voet D, Voet JG. 1990. Biochemistry. New York: John Wiley \& Sons. 1223 p.

Book with editors

Coutinho A, Kazatch Kine MD, editors. Autoimmunity physiology and disease. New York. WileyLiss; $1994.459 \mathrm{p}$.

Chapter from a book

Hausdorf G. Late effects of anthracycline therapy in childhood: evaluation and current therapy. In: Bricker JT, Green DM, D' Angio GJ, editors. Cardiac toxicology after treatment for childhood cancer. New York: Wiley-Liss; 1993. p 73-86.

For a book reference only include the page numbers that have direct bearing on the work described.

Keywords: On the title page, supply a minimum of 3 to 5 keywords, exclusive of words in the title of the manuscript. A guide to medical subject heading terms used by PubMed is available at http://www.nlm.nih.gov/mesh/MBrowser.html (http://www.nlm.nih.gov/mesh/MBrowser.html)

Abbreviations: Define abbreviations when they first occur in the manuscript and from there on use only the abbreviation. Whenever standardized abbreviations are available use those. Use standard symbols with subscripts and superscripts in their proper place.

Drug names: Use generic names. If identification of a brand name is required, insert it in parentheses together with the manufacturer's name and address after the first mention of the generic name. 
Eponyms: Eponyms (diseases or biologic entities named for persons) should not be used when standard descriptive terminology is available. Examples include club cells (formerly known as Clara cells); and granulomatosis with polyangiitis (formerly known as Wegener's granulomatosis). It is permissible to use the eponym in parenthesis at the first mention of the term in cases in which the eponym is still in common use.

Formatting Specific to Original Research Articles: Divide article into: Title Page, Summary/Abstract, Introduction, Materials and Methods, Results, Discussion, and References, starting each section on a new page. All methodology and description of experimental subjects should be under Materials and Methods; results should not be included in the Introduction. Please ensure the following appears in the appropriate section of your manuscript:

-a concise introductory statement outlining the specific aims of the study and providing a discussion of how each aim was fulfilled;

-a succinct description of the working hypothesis;

- a detailed explanation of assumptions and choices made regarding study design and methodology;

-a description of the reasons for choosing the type and number of experimental subjects (patients, animals, controls) and individual measurements; if applicable, information about how and why the numbers may differ from an ideal design (e.g., the number required for achieving $90 \%$ confidence in eliminating Type II error);

- specifics about statistical principles, techniques and calculations employed and, if applicable, methods for rejecting the null hypothesis;

-a concise comparison of the results with those of conflicting or confirmatory studies in the literature;

-a brief summary of the limitations of the scientific methods and results; and

-a brief discussion of the implications of the findings for the field and for future studies.

\section{-Tables}

Tables should not be included in the Main Document, but submitted as a separate DOC or RTF file. Number tables with Arabic numbers consecutively and in order of appearance. Type each table double-spaced on a separate page, captions typed above the tabular material. Symbols for units should be used only in column headings. Do not use internal horizontal or vertical lines; place horizontal lines between table caption and column heading, under column headings, and at the bottom of the table (above the footnotes if any). Use footnote letters ( $a, b, c$, etc.) in consistent order in each table. All tables should be referred to in the text. Do not submit tables as photographs and do not separate legends from tables.

\section{- Images}

Image files must be submitted in TIF or EPS (with preview) formats. Do not embed images in the Main Document. Number images with Arabic numbers and refer to each image in the text. The preferred form is $5 \times 7$ inches $(12.5 \times 17.5 \mathrm{~cm})$. Print reproduction requires files for full color images to be in a CMYK color space.

Please note authors are encouraged to supply color images regardless of whether or not they are amenable to paying the color reproduction fees. Color images will be published online, while greyscale versions will appear in print at no charge to the author. See Author Charges 
(http://onlinelibrary.wiley.com/journal/10.1002/(ISSN)10990496/homepage/ForAuthors.html\#AuthorCharges) below.

Journal quality reproduction requires grey scale and color files at resolutions yielding approximately 300 ppi. Bitmapped line art should be submitted at resolutions yielding $600-1200$ ppi. These resolutions refer to the output size of the file; if you anticipate that your images will be enlarged or reduced, resolutions should be adjusted accordingly.

Lettering on images should be of a size and weight appropriate to the content and the clarity of printing must allow for legibility after reduction to final size. Labeling and arrows on images must be done professionally. Spelling, abbreviations, and symbols should precisely correspond to those used in the text. Indicate the stain and magnification of each photomicrograph. Photographs of recognizable subjects must be accompanied by signed consent of the subject of publication. Images previously published must be accompanied by the author's and publisher's permission.

Image legends should be brief, and included as a separate DOC file under the heading: "Image Legends." When borrowed material is used, the source of the image should be shown in parentheses after its legend, either by a reference number or in full if not listed under References.

Online Supporting Information

Additional non-essential material such as text, appendices, tables, images, video, and soundtrack files may be submitted for posting as supporting information to an article. The scientific value of such material should be evident. The material should be submitted simultaneously with the manuscript so that it may undergo peer review. In naming these files, please note the file names should be preceded by the letter "E." For example "E-table 1, "Eimage 1," "E-text," etc.

Note that supporting online material is not typeset, nor proofread following the review process, so please ensure the material is accurate and free of typographical errors. Supporting material should be prepared in the same manner as the print material.

While supporting information does not appear in the print version, a notation is made that supporting material is available online.

Top of Page (http://onlinelibrary.wiley.com/journal/10.1002/(ISSN)1099-

0496/homepage/ForAuthors.html\#banner)

POLICIES/DISCLOSURE STATEMENTS

We recognize the importance of developing the highest ethical standards and we are committed to ethical publication practice. For more information on the publisher' $s$ policies, please see Wiley-Blackwell Guidelines on Publication Ethics and Best Practices www.wiley.com/bw/publicationethics (http://exchanges.wiley.com/publishingethics 252.html). Of particular importance is the section on Research Misconduct, which includes data fabrication, falsification, plagiarism, and inappropriate image manipulation.

Authors who submit to Pediatric Pulmonology should take heed of the following:

Conflict of Interest: Authors must indicate at the time of submission any potential conflict of interest (particularly of a fiscal nature) that may have a perceived influence on the results of the research. The existence of such does not automatically preclude publication. A conflict 
of interest statement should appear in the Acknowledgment section. For further information on Conflict of Interest please visit www.icjme.org (http://www.icmje.org/conflicts-of- interest/)

Experimental and Publication Ethics: Studies involving human subjects must conform to the guiding principles of the World Medical Association Declaration of Helsinki (http://www.wma.net/en/30publications/10policies/b3/). Human subjects must have given informed consent and the study must have been approved by the Committee on Human Research at the author(s) institution(s) and a statement to this effect must appear in the Methods section of the submitted article. It is also important to document in the Methods section that consent has been obtained from older children and adolescents. Similarly, animal studies must be approved by an Institutional Animal Research Review Board and a statement to this effect must appear in the Methods section. In addition, details of anesthesia and euthanasia must appear in the Methods section.

Plagiarism: It should be noted that Pediatric Pulmonology employs a plagiarism detection system. By submitting your manuscript to this journal you accept that your manuscript may be screened for plagiarism against previously published works. CrossCheck is a multi- publisher initiative to screen published and submitted content for originality. Pediatric Pulmonology uses iThenticate software to detect instances of overlapping and similar text in submitted manuscripts. To find out more about CrossCheck visit http://www.crossref.org/crosscheck.html (http://www.crossref.org/crosscheck.html).

Prior Publication: Manuscripts submitted to Pediatric Pulmonology may not have been published in any part or form in another publication of any type, professional or lay, including electronic publications, the exception being abstracts of no more than $\mathbf{4 0 0}$ words. Any material available via PubMed or other electronic sources is considered to have been published. When a question arises, the Editor-in-Chief will determine what constitutes duplicate publication. If duplicate publication is confirmed, the Editor-in-Chief will initiate a discussion with the sponsoring institution and the authors.

It is the responsibility of submitting authors to inform the Editor-in-Chief of potentially overlapping or related data either in submitted manuscripts or papers in press, and such manuscripts should be appended to the submission. If there is significant overlap in data with previously published articles this should be addressed by the author in the "Authors Comments" section during the submission process. In particular, giving reasons why the new submission should be published. The editors reserve the right to determine whether or not publication is warranted.

For further information on redundant or duplicate publication, please visit http://www.icmje.org (http://www.icmje.org/recommendations/browse/publishing-andeditorial-issues/overlapping-publications.html)

Clinical Trials: We endorse the Consolidated Statement of Reporting Trials (CONSORT Statement) Lancet 2002;357:1191-1194 which may be accessed at www.consort- statement.org (http://www.consort-statement.org/). In accordance with ICMJE standards, all clinical trials must be registered with a database that is publicly accessible such as http://clinicaltrials.gov/ However, other free of charge public registries are acceptable. For further information, please visit http://www.icmje.org/about-icmje/faqs/clinical-trials- registration/ (http://www.icmje.org/about-icmje/faqs/clinical-trials-registration/) 
Upon submission, authors are encouraged to submit names of experts who they deem appropriate to review their paper. Authors may also indicate persons to whom they do not wish the manuscript sent for review. In most cases, articles will be reviewed by at least two

authorities as well as the editorial staff to determine validity, significance, novelty, and potential impact on the field of contents and conclusions. The reviewers will be selected by the Editor-inChief, Associate Editors, and/or Editorial Board members. The selection will be made on the basis of expertise, impartiality, and equal distribution among the available experts, regardless of geographic origin of the manuscript or locations of the reviewers. Authors will be advised within the shortest possible time whether their paper is accepted, requires major or minor revisions, or is rejected. All necessary efforts will be made to ensure a timely review process.

Authors should note the time from submission to final decision can be shortened by a timely return of a revised manuscript when revision has been requested.

The Editor-in-Chief reserves the right to reject any submission deemed not suitable for the journal after an in-house review.

\section{FAST TRACK REVIEW}

If circumstances so warrant, a fast-track review of a paper may be requested in the cover letter. At the Editor-in-Chief's discretion, a fast-track review will be undertaken to expedite manuscripts that deserve rapid review and publication. Expedited peer review and publication is rare and is reserved for timely presentation of significant data. If fast-track review is requested in the cover letter, the corresponding author will be informed if expedited review has been granted or not.

\section{SUBMISSIONS FROM EDITORS AND EDITORIAL BOARD MEMBERS}

Pediatric Pulmonology strives to ensure that any submission from the Editor-in-Chief, Deputy Editor, the Associate Editors, or from a member of the journal's Editorial Board receives an objective and unbiased evaluation. This is achieved by assigning any research article submitted by the Editor-in-Chief, Deputy or Associate Editors to an impartial referee who can maintain the integrity of the review process. When appropriate, Pediatric Pulmonology may also utilize the services of Guest Editors who are familiar with the peer review processes and policies of the journal. Articles submitted by Editorial Board members undergo a blinded peer review process that is as stringent as for those authors who are not on the Board. All submitting authors are automatically blinded to all aspects of the review process.

\section{AUTHOR CHARGES (http://onlinelibrary.wiley.com/journal/10.1002/(ISSN)1099- 0496/homepage/AuthorCharges)}

Should authors wish for manuscript images appear in color in the print edition, color reproduction fees will be charged to the authors. Current color reproduction fees are $\$ 800$ per figure. Authors do, however, have the option of submitting color images for online publication, and greyscale images for the print edition at no charge, and we encourage authors to do so. For information on color charges, please contact Production Editor, at ppulprod@wwiley.com

\section{MANUSCRIPTS ACCEPTED FOR PUBLICATION}

The author identified as the formal corresponding author for the paper will receive an email prompting them to login into Author Services where via the Wiley Author Licensing Service (WALS) they will be able to complete a license agreement on behalf of all authors on the paper: 
Environmental risk factors for asthma in 13-14 year old African children

MPhil A Ayuk 2018

Online Open

OnlineOpen (http://olabout.wiley.com/WileyCDA/Section/id-406241.html) fulfills RCUK, Wellcome Trust, $\mathrm{NIH}$, and other funder mandates. Authors can use OnlineOpen to make their article open access and freely available to all on Wiley Online Library. Wiley also immediately deposit OnlineOpen articles in PubMed Central and PMC mirror sites. In addition, authors of OnlineOpen articles are permitted to post the final, published PDF of their article on a website, institutional repository or other free public server, immediately on publication.

With OnlineOpen, the author, the author' s funding agency, or the author' s institution pays a fee to ensure that the article is made open access.

If the OnlineOpen option is selected the corresponding author will have a choice of the following Creative Commons License Open Access Agreements (OAA):

(http://creativecommons.org/licenses/by-nc-nd/2.0/uk/)Creative Commons Attribution License OAA (http://creativecommons.org/licenses/by-nc/3.0/)

(http://creativecommons.org/licenses/by-nc-nd/2.0/uk/)

- Creative Commons Attribution Non-Commercial -NoDerivs License OAA

(http://creativecommons.org/licenses/by-nc-nd/2.0/uk/)

If you select the OnlineOpen option and your research is funded by The Wellcome Trust and members of the Research Councils UK (RCUK) you will be given the opportunity to publish your article under a CC-BY license supporting you in complying with Wellcome Trust and Research Councils UK requirements. For more information on this policy and the Journal' s compliant selfarchiving policy please visit: http://www.wiley.com/go/funderstatement (http://www.wiley.com/go/funderstatement)

For RCUK and Wellcome Trust authors click on the link below to preview the terms and conditions of this license:

Creative Commons Attribution License OAA (http://creativecommons.org/licenses/by- nc/3.0/)

Note to NIH Grantees: Pursuant to the NIH mandate, Wiley Blackwell will post the accepted version of contributions authored by NIH grant-holders to PubMed Central upon acceptance. This accepted version will be made publicly available 12 months after publication. For further information, see Wiley Blackwell' sNIH Policy Statement. (http://www.wiley.com/WileyCDA/Section/id-321171.html)

\section{Copyright Transfer Agreement}

If the OnlineOpen option is not selected, the corresponding author will be presented with the copyright transfer agreement (CTA) to sign on behalf of all authors.

To preview the terms and conditions of the open access agreements, or the copyright transfer agreement, please visit the FAQs hosted on Wiley Author Services. See http://authorservices.wiley.com/bauthor/faqs copyright.asp (http://authorservices.wiley.com/bauthor/faqs copyright.asp) and http://www.wileyopenaccess.com/details/content/12f25db4c87/Copyright--License.html (http://www.wiley.com/WileyCDA/Section/id-321171.html). 
Following acceptance, the corresponding author will be alerted by e-mail to access galley proofs in web-based proofing system. Corrections should be returned within 48 hours of receipt, as delays in returning galley proofs cause delays in publication. Alterations should be kept to a minimum. Costs of extensive alterations to the galley proof will be billed to the authors. All statements in (or omissions from) published manuscripts are the responsibility of the authors who are asked to carefully review proofs prior to publication.

REPRINTS

Reprints may be ordered at: https://caesar.sheridan.com/reprints/eorder/order (https://caesar.sheridan.com/reprints/eorder/order.php? $\underline{D B S}=A \& P U I D=10089 \& I U I D=4440 \&$ UNDO $=1 \&$ SERVICE $=2 \&$ ACCTUID $=75$ )

\section{APPEAL REQUESTS}

Authors who wish to request reconsideration of a rejected manuscript should direct their query to the Editor in Chief, Tom Murphy, murphyeditorppul@ hotmail.com (mailto:murphyeditorppul@ hotmail.com)or the PPUL editorial office, ppuledoffice@ wiley.com(http://onlinelibrary.wiley.com/journal/10.1002/(ISSN)10990496/homepage/ppuledoffice@ wiley.com.)Requests must include the manuscript ID and a detailed description of why the authors believe the paper should be reconsidered.

Appeal requests will be evaluated by the Editor-in-Chief to determine if an appeal will be permitted. These appeals will be approved on a very limited basis. If the appeal is allowed, instructions will be provided on how to resubmit your paper. Authors should not resubmit their rejected paper without prior approval from the Editors and the Editorial Office.

Requests that are sent elsewhere will not be considered.

\section{PRODUCTION QUESTIONS?}

Contact Production Editor at ppulprod@ wiley.com(mailto:ppulprod@ wiley.comppulprod)

QUESTIONS ABOUT YOUR SUBMISSION?

Contact the PPUL editorial office at ppuledoffice@ wiley.com

(http://onlinelibrary.wiley.com/journal/10.1002/(ISSN)1099-0496/homepage/ppuledoffice@ wiley.com)

\section{CONTACT THE EDITOR-IN-CHIEF}

Thomas Murphy, murphyeditorppul@ hotmail.com(mailto:murphyeditorppul@ hotmail.com) 